\title{
Linking Dendrometry and Dendrochronology in the Dominant Azorean Tree Laurus azorica (Seub.) Franco
}

\author{
Bárbara Matos 1,2, Lurdes Borges Silva 1,2,*, Ricardo Camarinho 1,3 , Armindo S. Rodrigues 1,3, \\ Ruben Rego ${ }^{1,2}{ }^{\mathbb{D}}$, Mariana Câmara ${ }^{1}$ and Luís Silva ${ }^{1,2}$ \\ 1 Faculdade de Ciências e Tecnologia, Universidade dos Açores, Rua Mãe de Deus 13A, \\ 9501-855 Ponta Delgada, Portugal \\ 2 InBIO, Rede de Investigação em Biodiversidade e Biologia Evolutiva, Laboratório Associado, CIBIO-Açores, \\ Universidade dos Açores, Apartado 1422, 9501-801 Ponta Delgada, Portugal \\ 3 IVAR, Institute of Volcanology and Risks Assessment, University of the Azores, \\ 9501-801 Ponta Delgada, Portugal \\ * Correspondence: lurdes.cb.silva@uac.pt; Tel.: +351-296-650-105
}

Received: 14 May 2019; Accepted: 21 June 2019; Published: 27 June 2019

\begin{abstract}
As in many archipelagos, the Azorean primary forest was largely cleared and replaced by secondary forest and grassland, the Azorean tree Laurus azorica (Seub.) Franco being one of the dominant trees in the remaining natural forests. Dendrochronological and dendrometric studies in the Azores mainly focused on non-indigenous trees, either used for timber (e.g., Cryptomeria japonica D. Don) or considered as invasive (Pittosporum undulatum Vent.). Therefore, this study aims to describe the growth ring anatomy of L. azorica, and to understand the relationship between dendrometric traits (e.g., trunk diameter at breast height; tree height), and the number of growth rings. Growth ring anatomy was accessed by wood anatomical preparation of microcore samples while tree age estimation was based on growth ring counts in wood cores taken at breast height and at base. A total of 145 trees were sampled, resulting in 262 increment cores, at six representative stands of laurel forest in São Miguel Island (Azores). The wood anatomical analysis confirmed the presence of clear annual ring boundaries, and a high structural similarity towards Laurus novocanariensis Rivas Mart., Lousã, Fern.Prieto, E.Días, J.C.Costa \& C.Aguiar. Age at tree base averaged 33 years, with $60 \%$ of the trees between 25 and 50 years old, and only about $15 \%$ above 50 years old. This suggests the existence of a secondary forest that is more recent than expected, probably due to human disturbance. The allometric models showed best fit when calculated by stand, suggesting the effect of local environmental conditions on growth rate. Radial growth rate was estimated at $0.68 \mathrm{~cm} \cdot y e a r^{-1}$. Given the known dominance of this species and the threats affecting natural forests, this baseline study will allow a better understanding of forest distribution and dynamics, and support a more effective forest management approach.
\end{abstract}

Keywords: tree age; tree growth rings; wood anatomy; laurel forest; primary forest; forest management; Azores

\section{Introduction}

Knowledge on tree growth rate and age-size relationships is the basis for understanding tree population dynamics and evaluating changes in both natural and managed forests, being crucial for sustainable forest restoration [1-4]. Dendrochronology techniques are commonly used in forest management to determine woody plant growth rates in seasonal climates $[2,5,6]$. Accurate tree age estimates are critical to a range of forest and ecological studies [7], for which a standard identification of the earlywood-latewood boundary is necessary [8]. 
The distribution of natural forests in the Azores Archipelago evolved in unique conditions, due to a pronounced isolation, relatively homogeneous climatic conditions and a limited number of native woody species [9-11]. According to Elias et al. [12], the best preserved and largest remnants of dominant woody natural vegetation in the Azores are located on São Miguel, Pico, Terceira, and Flores islands. Four altitudinal belts have been recognized [12]: Coastal (Erica-Morella coastal woodlands); lowland (Picconia-Morella lowland forests); submontane/montane (Laurus submontane forests, Juniperus-Ilex montane forests and Juniperus montane woodlands); and altimontane/alpine (Calluna-Juniperus altimontane scrublands, Calluna-Erica subalpine scrubland and Calluna alpine scrubland). Changes in land use have drastically reduced the area occupied by natural forest, and new threats include climate change, which may affect the distribution of dominant species of bryophytes and vascular plants, leading to changes in the structure and distribution of plant communities $[13,14]$. Moreover, non-indigenous invasive species such as Pittosporum undulatum Vent., Hedychium gardnerianum Sheppard ex Ker-Gawl., Leycesteria formosa Wall., Clethra arborea Aiton and tree ferns (Sphaeropteris cooperi (F.Muell.) R.M.Tryon; Sphaeropteris medullaris Bernh and Dicksonia antarctica Labill.), are currently threatening the conservation of endemic Azorean species and natural forests [2-4,15-19].

Dendrochronological studies performed in the Azores mainly addressed exotic species, such as Pittosporum undulatum following a possible strategy of biomass valorization [2,4], and Pinus pinaster Aiton in order to determine the limiting factors for tree growth in the Azores [20]. Therefore, a lack of research dedicated to other native or endemic trees is evident. Among Azorean endemic trees, Laurus azorica (Seub.) Franco is considered as a relic of the Tertiary Mediterranean flora [21], being a characteristic and dominant element in submontane forests and woodlands which are reduced to only $5 \%$ of their original cover $[9,22]$. There are different visions regarding Laurus taxonomy. If for some authors L. azorica is distinguishable from Laurus Nobilis L. and L. novocanariensis Rivas Mart., Lousã, Fern.Prieto, E.Días, J.C.Costa \& C.Aguiar [23], for others phylogeographic evidence supports the existence of only one Laurus taxon [23,24]. A potential threat to L. azorica is the possible hybridisation with Laurus nobilis as intermediate forms are sometimes found. However, species delimitation within the genus Laurus is highly controversial and hybrid occurrence has not been confirmed $[25,26]$.

A few studies have focused on the Lauraeacea family in some of the Macaronesian islands. Câmara [27] analyzed forest structure and estimated tree age at breast height at two stands of laurel forest located in a protected area, and Rego et al. [28], with a focus on the ecological characterization of unprotected areas in São Miguel Island, also analyzed growth rings at a laurel forest invaded by Clehtra arborea. Other studies focused on Laurus novocanariensis growth rings, namely in Tenerife laurel forest, where wood structure was characterized, and it was shown that the whole cross section of its diffuse porous stems can be functional, even when many individual vessels are embolized [21,29]. Recently, the potential of the neotropical lauraceae in dendrochronology was revised by Reis-Avila and Oliveira [30], showing that growth rings generally include a boundary marked by an abrupt transition between thick-walled and radially flattened fibers in the latewood of a ring, and thin-walled earlywood fibers of the consecutive ring; or, otherwise, a marginal parenchyma band delimiting tree-rings. The same authors concluded that the Lauraceae have distinct, synchronic and climate-sensitive tree-rings, and recommended their use in dendrochronological studies.

This work focuses on tree ring analysis of Laurus azorica, an endemic and dominant tree in the Laurel forests on the Azores Islands. Laurus azorica growth rings have been reported to be easily identified, due to the existence of a sharp transition between latewood and earlywood, that is evident macroscopically [27].

In this context, the main goals for this work were a characterization of L. azorica growth ring anatomy, in order to confirm the descriptions given for other Lauraceae, and the establishment of age-size relationships and growth rate estimates, using models that relate dendrometric traits with tree age. 


\section{Materials and Methods}

\subsection{Study Area}

The Azores archipelago, situated in the north Atlantic Ocean $\left(36^{\circ} 55^{\prime}-39^{\circ} 43^{\prime} \mathrm{N}\right.$ and $\left.25^{\circ} 00^{\prime}-31^{\circ} 15^{\prime} \mathrm{W}\right)$, is composed of three island groups: Eastern (Santa Maria and São Miguel islands), Central (Terceira, Pico, Faial, São Jorge and Graciosa islands) and Western (Flores and Corvo islands). This study was carried out in São Miguel (Figure 1), the largest island, with $745 \mathrm{~km}^{2}$, a coastline length with $213 \mathrm{~km}$ and the highest peak at $1105 \mathrm{~m}$ [31].

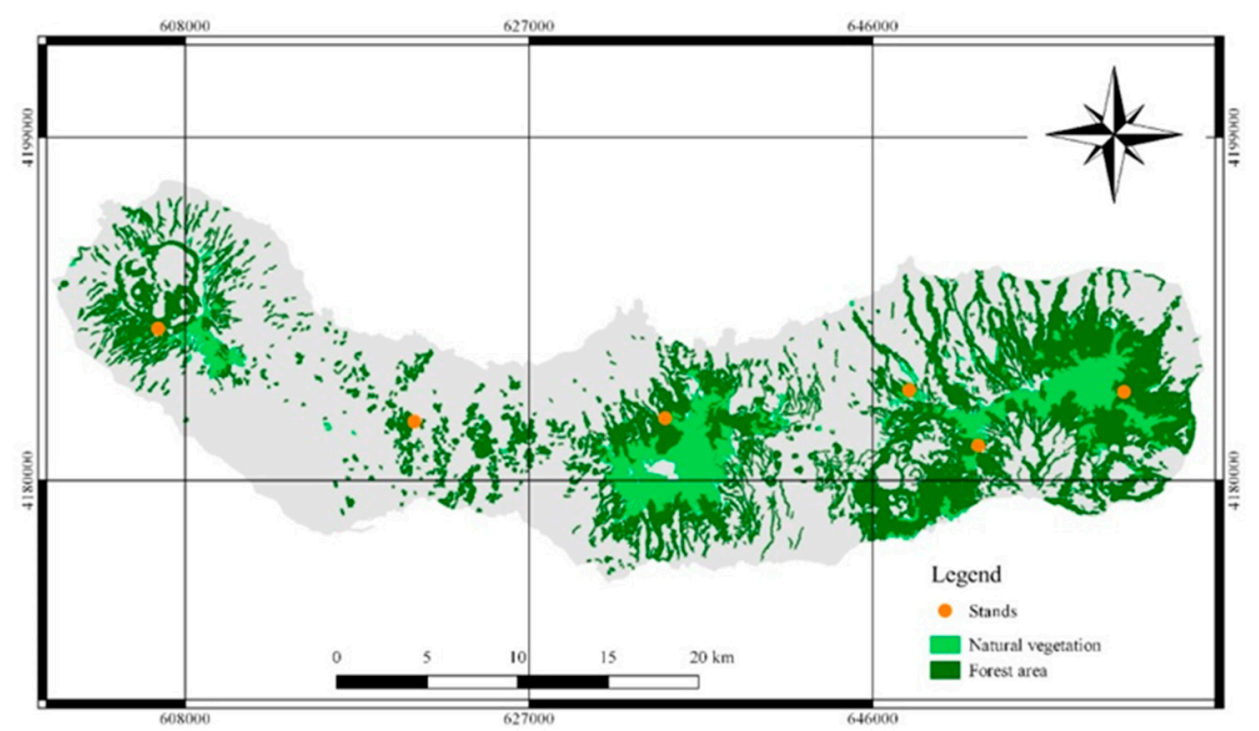

Figure 1. Distribution of the six selected stands of natural vegetation in São Miguel Island. From left to right: Sete Cidades; Pinhal da Paz; Lombadas; Achada das Furnas; Povoação; Tronqueira. In the map, natural vegetation is not entirely forest.

While there is a variation in the climatic conditions from one extreme of the archipelago to the other, and a significant altitudinal variation within each island, the Azorean climate might be classified as wet mesothermic with oceanic traits, low thermal amplitude and a mean annual temperature of $17^{\circ} \mathrm{C}$ at sea level. Rainfall is generally high and rainfall ranges from 1500 to more than $3000 \mathrm{~mm}$ per year, increasing with altitude and from east to west [32]. Wind is also considered as a relevant factor in the distribution of forests in the case of the Azores, being a limiting factor, particularly at very exposed locations, both at low and high elevation [9]. Of the $2350 \mathrm{~km}^{2}$ that correspond to the total land area in the Azores, about $43 \%$ is now dominated by pastures, planted or exotic forests (22\%), with natural vegetation occupying about $13 \%[33,34]$. Table 1 includes a climatic characterization and the type of soil at each of the study sites. 
Table 1. Characterization of the sampling stands of Laurus azorica (Seub.) Franco trees in São Miguel Island. Elevation (E, m), number of trees (N), number of cores at breast or at the base (CB, CA), Annual Mean Temperature (MT, $\left.{ }^{\circ} \mathrm{C}\right)$, Maximum Temperature of the Warmest Month (TW, $\left.{ }^{\circ} \mathrm{C}\right)$, Minimum Temperature of the Coldest Month $\left(\mathrm{TC},{ }^{\circ} \mathrm{C}\right)$, Annual Temperature Range $\left(\mathrm{TR},{ }^{\circ} \mathrm{C}\right)$, Annual Precipitation (AP, mm), Precipitation of the Wettest Quarter (PW, mm), Precipitation of the Driest Quarter (PD, mm). Soil Types: Ins-Insaturated; Ferr-Ferruginous; Shal Aloph-Shallow Alophanic soil; Reg-Regosoil. Climatic data from Karger et al. [35] and Soil data from Ricardo et al. [36]. Native and exotic species as mentioned in the text.

\begin{tabular}{|c|c|c|c|c|c|c|c|c|c|c|c|c|c|c|c|c|}
\hline \multirow{2}{*}{ Stands } & \multirow{2}{*}{ Code } & \multirow{2}{*}{$\mathrm{E}(\mathrm{m})$} & \multicolumn{3}{|c|}{ Sampling } & \multicolumn{8}{|c|}{ Physical Description } & \multirow[b]{2}{*}{ Native } & \multirow{2}{*}{$\begin{array}{c}\text { Main Species } \\
\text { Exotic } \\
\end{array}$} & \multirow{2}{*}{$\begin{array}{c}\begin{array}{c}\text { Other } \\
\text { Information }\end{array} \\
\text { Protection }\end{array}$} \\
\hline & & & $\mathbf{N}$ & CB & CA & MT & TW & TC & TR & AP & PW & PD & Soil Type & & & \\
\hline Lombadas & LO & 569 & 25 & 25 & 0 & 14 & 22 & 7 & 15 & 1684 & 641 & 167 & Ins And & $\begin{array}{l}\text { L. azorica, } \\
\text { I. azorica, } M \text {. faya }\end{array}$ & $\begin{array}{l}\text { P. undulatum, } \\
\text { H. gardnerianum }\end{array}$ & $\begin{array}{c}\text { Habitat/Species } \\
\text { Management } \\
\text { Area }\end{array}$ \\
\hline $\begin{array}{l}\text { Achada das } \\
\text { Furnas }\end{array}$ & $\mathrm{AF}$ & 600 & 20 & 20 & 0 & 13 & 22 & 7 & 15 & 2108 & 789 & 221 & $\begin{array}{l}\text { Shal Aloph } \\
\text { Ins/Ferr And }\end{array}$ & $\begin{array}{l}\text { L. azorica, } \\
\text { I. azorica }\end{array}$ & $\begin{array}{c}\text { C. arborea, } \\
\text { P. undulatum, } \\
\text { H. gardnerianum }\end{array}$ & Unprotected \\
\hline Pinhal da Paz & PP & 322 & 25 & 31 & 29 & 15 & 23 & 8 & 15 & 1294 & 494 & 133 & Shal Aloph Reg & L. azorica, M. faya & $\begin{array}{l}\text { P. undulatum, } \\
\text { H. gardnerianum }\end{array}$ & $\begin{array}{l}\text { Recreational } \\
\text { Forest Reserve }\end{array}$ \\
\hline Sete Cidades & SC & 599 & 25 & 29 & 28 & 13 & 22 & 7 & 15 & 1850 & 698 & 195 & Ins And & $\begin{array}{l}\text { L. azorica, } \\
\text { I. azorica, M. faya }\end{array}$ & $\begin{array}{l}\text { C. japonica, } \\
\text { P. undulatum, } \\
\text { H. gardnerianum }\end{array}$ & $\begin{array}{l}\text { Protected } \\
\text { Landscape }\end{array}$ \\
\hline Tonqueira & TR & 629 & 25 & 25 & 25 & 13 & 22 & 6 & 15 & 2092 & 816 & 199 & $\begin{array}{l}\text { Shal Aloph } \\
\text { Ins/Ferr And }\end{array}$ & $\begin{array}{l}\text { L. azorica, } \\
\text { I. azorica, M. faya, } \\
\text { J. brevifolia }\end{array}$ & $\begin{array}{c}\text { C. arborea, } \\
\text { H. gardnerianum }\end{array}$ & $\begin{array}{c}\text { Habitat/Species } \\
\text { Management } \\
\text { Area }\end{array}$ \\
\hline \multirow[t]{2}{*}{ Povoação } & $\mathrm{PO}$ & 541 & 25 & 25 & 25 & 14 & 23 & 7 & 15 & 1557 & 596 & 152 & $\begin{array}{l}\text { Shal Aloph } \\
\text { Ins/Ferr And }\end{array}$ & L. azorica I. azorica & H. gardnerianum & Unprotected \\
\hline & Total & & 145 & 155 & 107 & & & & & & & & & & & \\
\hline
\end{tabular}




\subsection{Target Species}

The Lauraceae family is classified within the order Laurales, being widely distributed in tropical and subtropical climates, including approximately 45 genera and 2850 species [37,38]. Molecular phylogenetic studies clearly show the monophyly of the family [39] and while intergeneric relationships in Lauraceae are becoming established [40-42], generic circumscriptions are plagued by polyphyly [41]. The family has an important ecological role, namely in the Atlantic Forest with many representatives contributing to the species richness of this biome [43]. In Macaronesia it is also one of the plant families structuring the laurel forest in the Azores, Madeira, and in the Canary Islands [44].

The Laureacea family presents a high number of species with a diversity of uses, from cooking, to paper factoring, timber works, constructions, chemical industries and folk medicine. This family has a considerable economic value with a wide range of applications, which has led to an increasing exploitation over the years, making several species vulnerable or endangered [45]. A variety of wood types from this family are used for carpentry and paper factoring while aromatic and oil producing species are mostly used as raw-materials in industry, the range of applications being very wide, and using several plant parts (i.e., timber, leaves, fruits and seeds) [46].

The conservation status of L. azorica (Seub.) Franco is currently Least Concern according to the IUCN (International Union for Conservation of Nature) criteria, the population numbers are large and the trend is now stable, and although the species has a restricted area of occupancy, it is not declining $[19,47]$. Laurus azorica is one of the major components of the laurel forest but it is also present in other types of forest, namely in four zonal vegetation types [12]: Picconia-Morella lowland forests (100-300 m), Laurus submontane forests (300-600 m), Juniperus-Ilex montane forests (600-900 m), and less frequently in Juniperus montane woodlands (700-1000 m). It is also found in lava flows, margins of cultivated land, coastal scrubland, mountain scrubland and forested peat bogs. It is a dioecious tree that can reach heights from 5 to $20 \mathrm{~m}$, although with an average height around $10 \mathrm{~m}$ [18]. It is distinguishable by an upright trunk branching at a short distance from the base, alternate, hairy young leaves and stems, the old leaves becoming glabrous.

\subsection{Stand Characterization}

The studied stands (Figure 1) include Laurus azorica (Seub.) Franco trees of different size classes, growing at remaining laurel forests, in São Miguel Island. In order to maximize the representativeness of the study we distributed all six sampling plots through the typical laurel forests of the island (Figure 1, Table 1), mostly inside protected areas, except Achada das Furnas and Povoação.

\subsection{Field Sampling}

The study was carried out between March and May 2018 and includes a total of trees of different size classes, growing at remaining laurel forests, in São Miguel Island (Figure 1). A total of 145 L. azorica (Seub.) Franco trees were sampled (Table 1). At each site, trees were selected following a stratified random sampling scheme, according to the following diameter classes in $\mathrm{cm}:(<5,5-10,10-15,15-20$, $>20 \mathrm{~cm}$ ). However, the final sample was dependent on the individuals that were available at each stand.

For each tree, the following dendrometric parameters were taken [3,5,8]: Diameter at Breast Height (at $130 \mathrm{~cm})$, Diameter at Base $(20 \mathrm{~cm})$ and Maximum Tree Height. Diameters were measured with a diameter measuring tape, Friedrich Richter Messwerkzeuge GmbH \& Co. KG, Speichersdorf, Germany, and total tree height using Vertex IV 360_and Transponder T3, Haglöf Sweden AB, Långsele, Sweden.

Wood samples were collected at breast height [48] for tree age determination. Whenever possible, samples were also taken at the base (about $20 \mathrm{~cm}$ above soil), but this was dependent on tree and terrain features. In those cases, trunk diameter was also registered at that level. Increment cores $(5 \mathrm{~mm}$ ) were collected using a Pressler borer Haglöf Sweden AB, Långsele, Sweden while microcores $(2 \mathrm{~mm})$ were sampled using a Trephor University of Padua, Costruzioni Meccaniche Carabin C., Valle di Cadore, Belluno, Padova, Italy [49]. For the latter, a total of 14 individual trees were sampled to 
allow for possible wood anatomical variation. Wood microcores were immediately immersed in a fixative solution of Formalin, Acetic acid and Alcohol (FAA) CHEM-LAB, Zedelgem, Belgium and transported in Eppendorf ${ }^{\circledR}$, Deltalab S.L., Barcelona, Spain, tubes to the lab.

\subsection{Wood Sample Preparation for Macroscopic Analysis}

Samples were allowed to air-dry in wood supports for at least one week [2], and were mounted on wood supports with glue. Sample surface preparation was carried out by polishing with sandpaper of increasing gradation [50]-100, 180, 220, 320, 400 and 600.

The number of tree rings was estimated through counting under a stereomicroscope (Leica-Zoom 2000, Model NO.Z30 V, 240 vac, maximum magnification of 100×, Leica Microsystems Inc., Buffalo Grove, IL, USA). Images were taken using Stemi 2000-C with built-in 6 V, 10 W, 230 vac, and Zeiss ZEN software. Fisher Bioblock Scientific, Cedex, France; Carl-Zeiss-Straße, Oberkochen, Germany.

\subsection{Wood Sample Preparation for Microscopic Analysis}

Wood microcores were processed following a standard protocol [51]. Progressive dehydration with alcohol, clearing with D-limonene Across Organic ${ }^{\mathrm{TM}}$ Thermo Fisher Scientific and paraffin infiltration were performed in an automatic tissue processor. After that, microcore samples were paraffin blocked, and trimmed for section cutting. In a rotary microtome, sections with a thickness of $8 \mu \mathrm{m}$ were prepared, transferred to Glycerin-Albumin Sigma-Aldrich Corporation, St. Louis, MO, USA coated slides, and stored at $37^{\circ} \mathrm{C}$ overnight. Two sets of histological slides were prepared for two distinct staining methods. Paraffin was removed using D-limonene and rehydration was performed with alcohol solutions CHEM-LAB, Zedelgem, Belgium with decreasing concentration. The first set of slides was stained with Toluidine Blue Sigma-Aldrich Corporation, St. Louis, MO, USA and the second set was stained with a water solution of $100 \mathrm{~mL}$ demineralized water, Astrablue (150 mg), Santa Cruz Biotechnology, Dallas, TX, USA safranin (40 mg) CHEM-LAB, Zedelgem, Belgium and 2 mL acetic acid CHEM-LAB, Zedelgem, Belgium (adapted from [52]). Sections were then dehydrated and mounted in DPX (Distrene Plasticizer Xylendene The samples were observed under a light microscope LEICA DM1000 Leica Microsystems Inc., Buffalo Grove, IL, USA, associated to CoolSnap-Pro, Media Cybernetics and images taken using Image Pro-Plus 5.0. software.

\subsection{Statistical Analyses}

\subsubsection{Dendrometric Traits}

Descriptive statistics and graphical comparisons were produced for tree diameter, height and age (based on the number of rings). A preliminary analysis revealed the existence of outliers when analyzing data per site. However, when grouping the trees by size class $(<10,10-20,>20 \mathrm{~cm})$, irrespective of sampling site, no outliers were detected. Boxplot and bar chart representations were obtained for the above listed parameters, according to the site, the type of sample (tree base or breast height) or the diameter class. We used Kruskal-Wallis $(K-W)$ test, followed by a multiple comparison test, (i) to compare sites for tree height, trunk diameter, and tree age, and (ii) to compare diameter classes for tree height and tree age. We used Mann-Whitney $(M-W)$ test to compare samples at base of the tree or at breast height, both for trunk diameter and tree age. Data analysis was made using IBM SPSS version 24 .

\subsubsection{Annual Increment}

From a total of 101 base/breast sample pairs, the average number of years to attain breast height and radial growth rate were calculated. To estimate radial growth, Periodic Annual Increment (PAI) was used:

$$
P A I=\frac{D_{1}-D_{2}}{A g e_{1}-A g e_{2}}
$$


where $D_{1}$ is the diameter at base (20 cm above ground), $D_{2}$ is the diameter at breast height $(130 \mathrm{~cm}$ above ground), $A g e_{1}$ is the number of years at base, and $A g e_{2}$ is the number of years at breast height for each tree $[2,53]$.

\subsubsection{Relationship between Tree Age and Dendrometric Traits}

Models relating tree age with other dendrometric variables (e.g., diameter at breast height, tree height, crown diameter, crown volume, leaf area) are available for different species and different geographic areas [54,55], including the Azores [2]. In our study, allometric equations were used to relate tree age, as derived by tree ring counts, with diameter at breast height, tree height and basal area.

We followed the general procedures for the calculation of allometric equations that have been previously described [2-4], including data logarithmization in order to ensure homocedasticity. We evaluated candidate models using corrected Akaike's Information Criterion (AIC), square root mean error and mean relative error $[2-4,56]$. Statistical analyses were performed using $R$ software, version 3.2.3 [57].

\section{Results}

\subsection{Tree Ring Structure}

We found clear growth ring patterns in L. azorica (Seub.) Franco increment cores and wood samples taken in São Miguel Island (Figure 2). Some of the samples showed unclear rings transitions, presenting some different coloration or other anomaly, detected in field or laboratory work, which made tree ring counting difficult or impossible (Figure 2B). Therefore, those samples were not considered in the study. The diffuse-porous structure of the wood was clearly visible in the macroscopic preparations (Figure 2A,D).

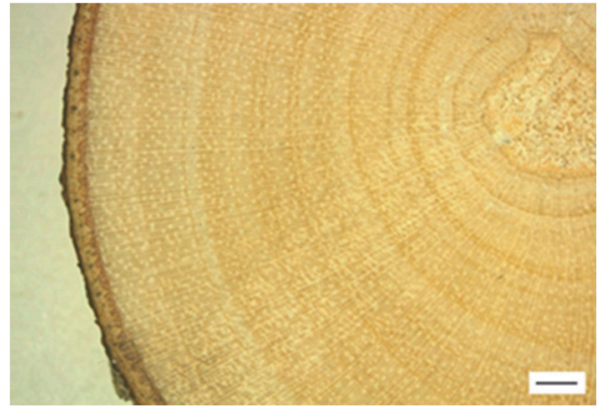

(a)

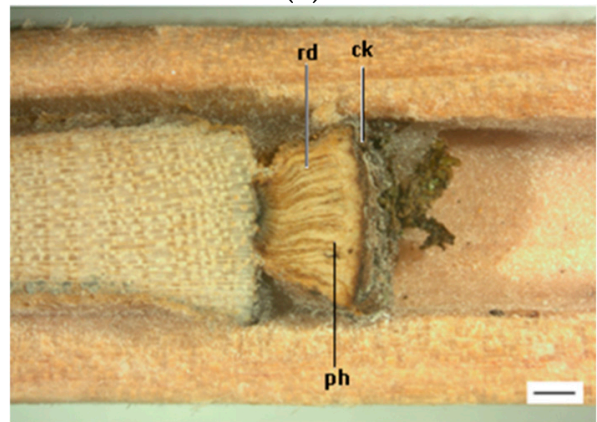

(c)

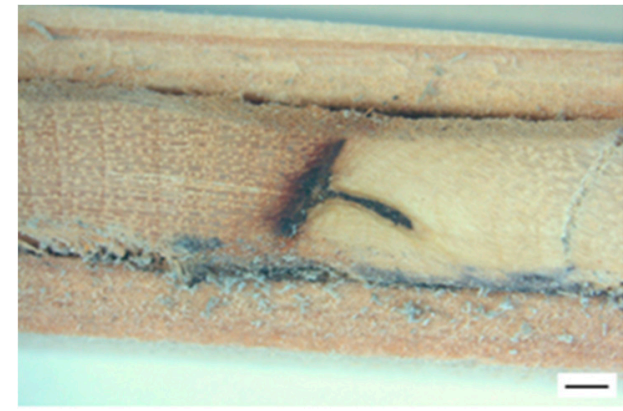

(b)

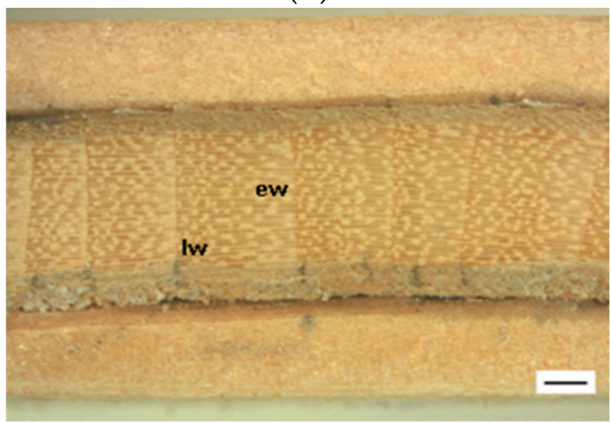

(d)

Figure 2. Macroscopic view of L. azorica (Seub.) Francostem disc (a) and of increment cores (b,c,d) taken in São Miguel Island. (a) Pith, distinct tree rings with latewood (lw) and earlywood (ew), and bark. (b) Example of some of the anomalies found in increment cores. (c) Younger tree rings close to cambium, phloem (lighter, ph), ray dispersion (darker, rd) and cork (ck). (d) Tree rings with distinct ring boundaries, and different coloration of early (ew) and latewood (lw), with vessels equally distributed along the ring. Scale bar $1 \mathrm{~mm}$. 


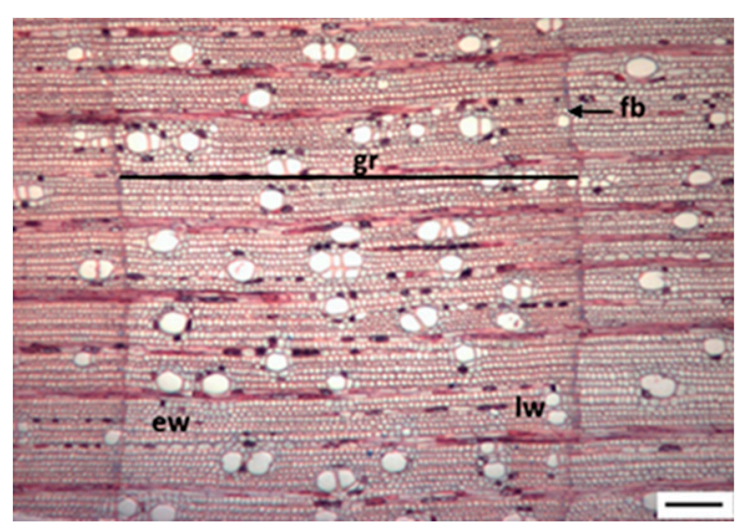

(a)

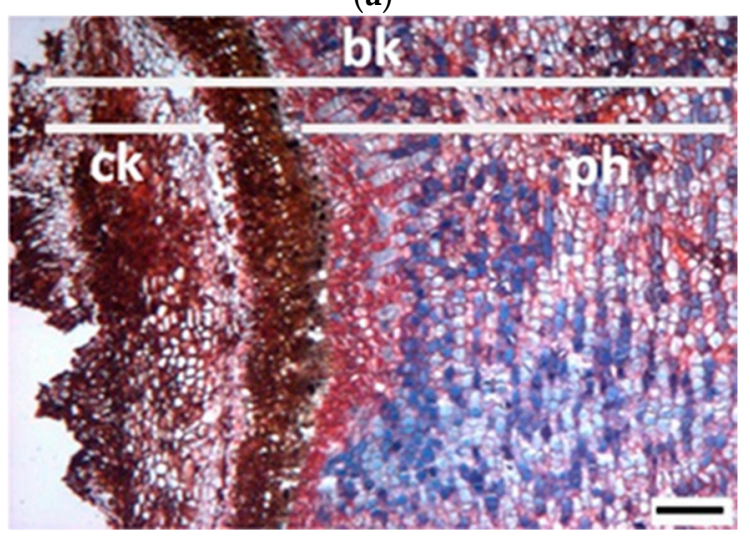

(d)

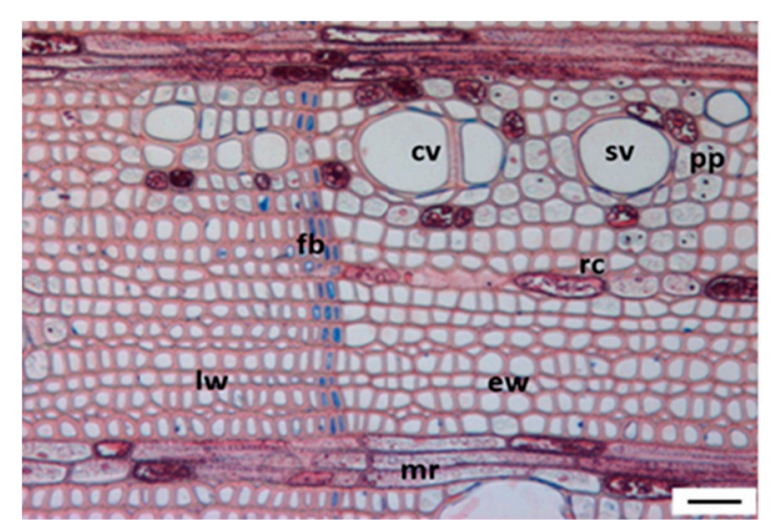

(b)

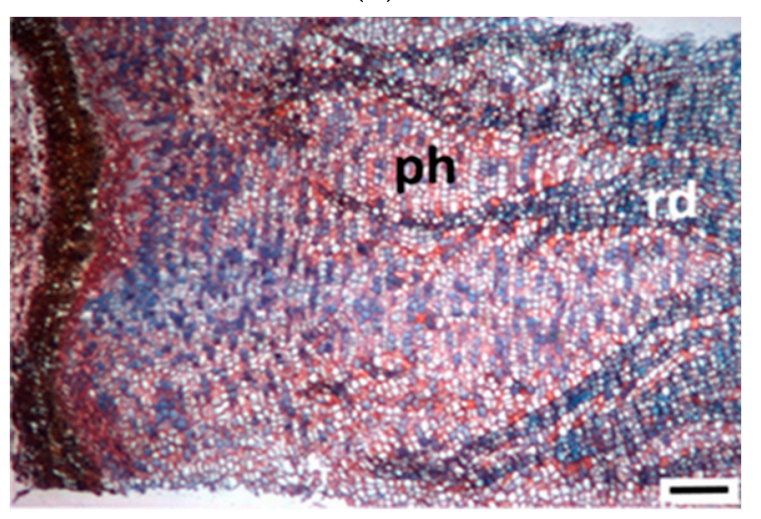

(e)

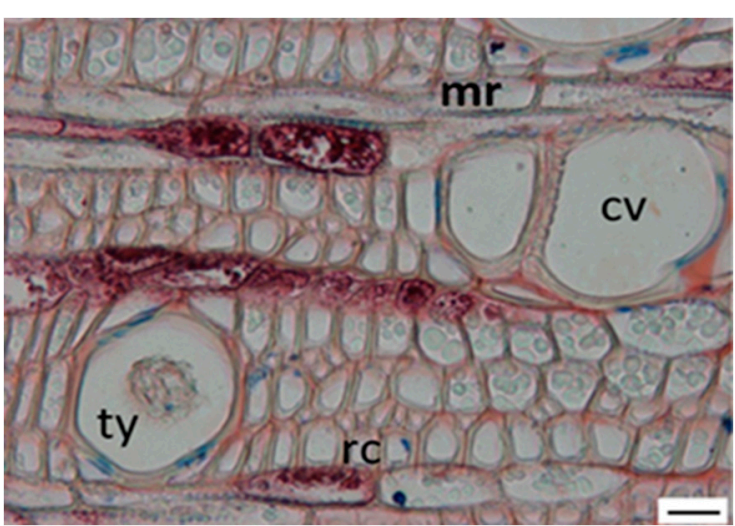

(c)

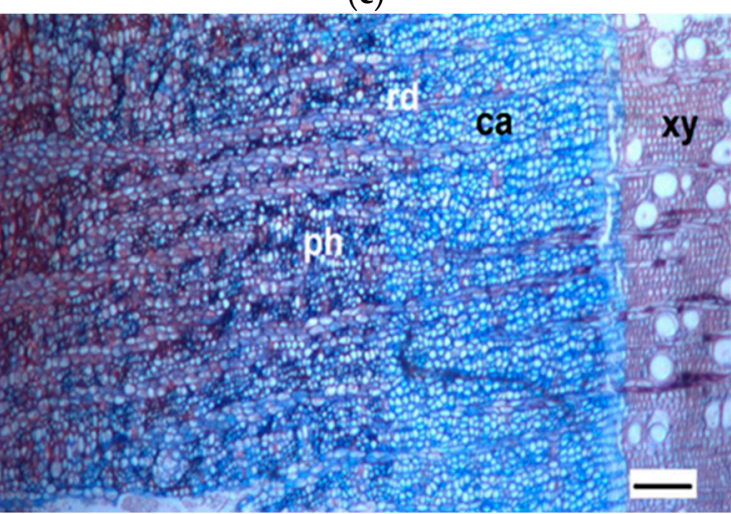

(f)

Figure 3. Cross-section view of L. azorica (Seub.) Franco tree rings under light microscope: First row: (a) General view of growth rings (gr) with thick-wall fibrous boundaries (fb), earlywood (ew) and latewood (lw), xylem rays and vessels with equal size and distribution along annual ring (scale bar $200 \mu \mathrm{m}$ ); (b) Growth ring boundary (fb), paratracheal parenchyma cells around vessels (pp), multiseriate rays (mr), solitary vessels (sv), clustered vessels (cv) and reddish cells (rc) (scale bar $50 \mu \mathrm{m}$ ); and (c) Unlignified tylosis (ty) (scale bar $25 \mu \mathrm{m})$. Second row: (d,e), cross section view of bark with phloem wood: (d) Simple construction of phloem, with phloem elements difficult to distinguish but differentiated from ray dilatation (scale bar $150 \mu \mathrm{m}$ ); (e) Bark layers. rd—ray dilatation; ph—phloem; ck—cork layers; bk-bark (scale bar $200 \mu \mathrm{m}$ ); (f) Cross-section of cambial zone from L. azorica, cambium is crossed by xylem rays that dilate in phloem to the bark. xy—xylem; ca-cambium; ph—phloem; rd-ray dilatation (scale bar $200 \mu \mathrm{m}$ ). 
Laurus azorica xylem showed a diffuse-porous structure, with solitary or clustered vessels, in radial oriented groups, randomly distributed and with no relationship with the ring boundaries (Figure 3A). Ring boundaries, the transition from latewood to earlywood, are marked by thick-walled, radially flattened fibers (Figure 3A,B). Reddish cells appear randomly distributed across tree rings due to dye retention (Figure 3A,B). Xylem vessels appear solitary or in clusters. Series of radial rays produced in cambium are arranged in parallel and elongated, connecting the medullar and cortical areas (Figure 3B). Xylem fibers in latewood tend to show a relatively smaller cellular lumen and thicker cell wall, as compared with earlywood fibers (Figure 3B). Small, thin-walled, unlignified tylosis were also observed (Figure 3C).

The transition between xylem, vascular cambium and phloem is evident in cross-section (Figure 3, second row). Cambium is crossed by xylem rays that dilate into phloem and to the bark. An outermost cork layer is also evident (Figure 3, second row).

In longitudinal view, plates were observed between consecutive xylem vessels, intervessel pits were visible along the xylem vessels, and multiseriate rays were common (Figure 4).
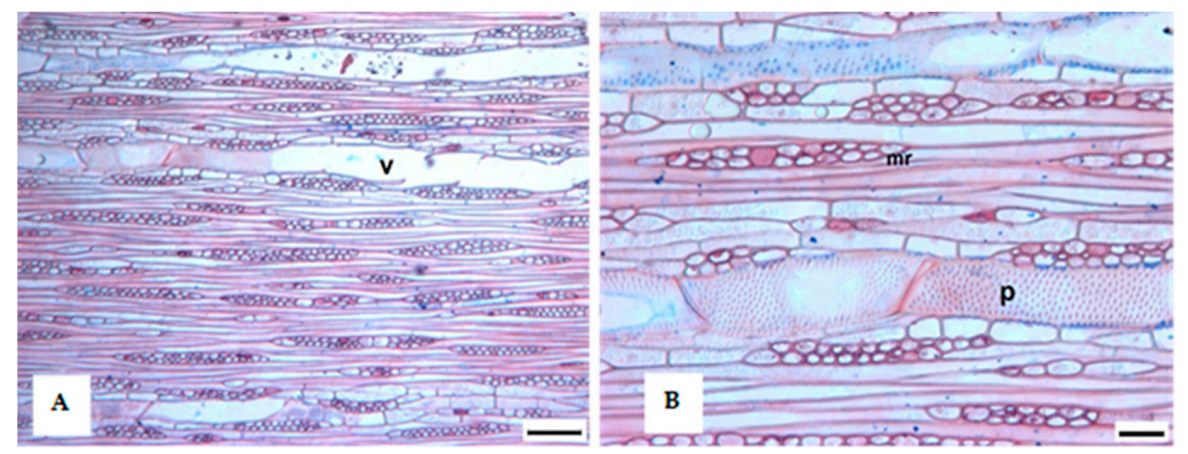

Figure 4. Tangential section from L. azorica (Seub.) Franco secondary xylem. (A) General view including xylem vessels (v) and multiseriate rays (scale bar $150 \mu \mathrm{m}$ ). (B) A more detailed view showing a closer perspective of multiseriate rays (mr) and the presence of intervessel pits (p) (scale bar $50 \mu \mathrm{m}$ ).

\subsection{Dendrometric Traits}

From the total of 256 samples collected at base and breast height a high amplitude of values was found for all the analyzed parameters (Figure 5). Trunk analysis has shown that the diameter of the mostly sampled trees ranges between 5 and $25 \mathrm{~cm}$ (Figure 5A).
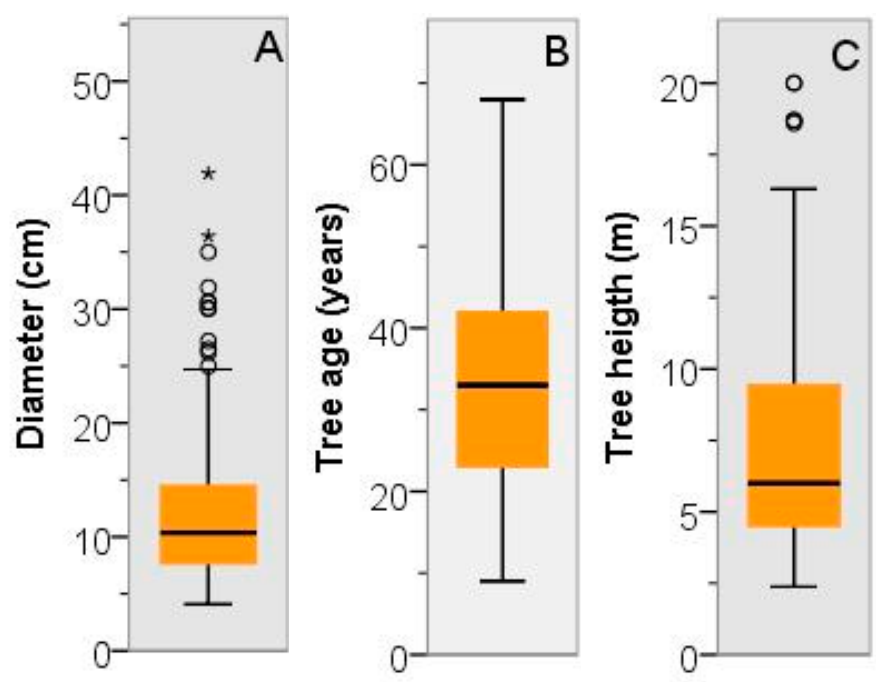

Figure 5. The estimated distribution of trunk diameter (A), tree age (B), and maximum height (C), of the 256 L. azorica (Seub.) Franco samples measured in São Miguel Island. 
Estimated tree ages showed high variability, ranging from about 10 to almost 70 years old. For all the collected samples the central quartiles of tree age distribution concentrated between 23 and 42 years (Figure 5B). Tree height ranged from about 3 up to $20 \mathrm{~m}$ (Figure 5C).

Differences between stands were found in the distribution and variability of dendrometric data (i.e., tree age, maximum tree height, diameter at breast height, diameter at base). Tree height ranged from about $7 \mathrm{~m}$ in Achada das Furnas up to $20 \mathrm{~m}$ in Povoação. For most stands, tree height was concentrated between 4 and $9 \mathrm{~m}$, except for Povoação, where the central quartiles ranged from about 9 to $14 \mathrm{~m}$ (Figure 6A). In general, diameter at the base was slightly larger than diameter at breast height, with the former ranging from 5.2 to $41.9 \mathrm{~cm}$ and the latter from 4.1 to $36.4 \mathrm{~cm}$ (Figure 6B). Povoação showed the largest trunk diameters, differing from the remaining sites with values concentrated below $15 \mathrm{~cm}$ (Figure 6B). We found a remarkable variability in tree age, varying between 12 and 68 years at base, and between 9 and 62 years at breast height (Figure 6C). Minimum age was found at Pinhal da Paz and maximum age at Povoação. In addition, a large variation was found at each stand. Povoação, Sete Cidades and Tronqueira stands were those with tree rings more concentrated at older ages (Figure 6C).

Three diameter classes were created $(<10,10-20,>20 \mathrm{~cm})$, to better understand the relationship between trunk diameter, tree height and tree age. Only 24 individuals represented the 3 rd diameter class, while 121 and 111 represented the 1st class and 2nd classes, respectively. As diameter class increased also tree height increased (Figure 6D). In the 1st, 2nd and 3rd classes, tree height was concentrated around median values of 5 , below 7.5 and between 12.5 and $15 \mathrm{~m}$, respectively. As expected, an increase in tree age with diameter was found (Figure 6E). Considerable overlap was found between tree age estimates obtained at the base and at breast height for the 1st and 2nd diameter classes, but not so much for the 3rd diameter class (Figure 6E).

Differences in age structure between stands were clear when representing tree age distribution for the three diameter classes (Figure 7). Most populations were concentrated in the 1st and 2nd diameter classes, while Povoação was concentrated in the 2nd and 3rd classes. Again, a considerable overlap of the distribution of the estimated ages in the 1st and 2nd diameter classes was found, namely for Lombadas and Sete Cidades, and also in the 2nd and 3rd classes for Povoação (Figure 7).

There were significant differences between sites for tree height $\left(K-W\right.$ test, $\chi^{2}=109.027, d f=5$, $p<0.001)$ trunk diameter $\left(K-W\right.$ test, $\left.\chi^{2}=88.102, d f=5, p<0.001\right)$, and tree age $\left(K-W\right.$ test, $\chi^{2}=95.774$, $d f=5, p<0.001$ ), forming three homogeneous groups (results of a multiple comparison test, with $p>0.05$ within each group): (i) Povoação; (ii) Sete Cidades, Lombadas and Pinhal da Paz; and (iii) Achada das Furnas and Tronqueira. As expected, there were significant differences between samples at the base of the tree or at breast height, both for trunk diameter $(M-W$ test, $U=5574.0$, $p<0.001$, mean rank base $=150.90$, mean rank breast $=113.17)$ and tree age $(M-W$ test, $U=5579.5$, $p<0.001$, mean rank base $=148.93$, mean rank breast $=114.52$ ). As expected, there were significant differences between the three defined diameter classes both for tree height $\left(K-W\right.$ test, $\chi^{2}=78.147$, $d f=2, p<0.001)$ and tree age $\left(K-W\right.$ test, $\left.\chi^{2}=64.779, d f=2, p<0.001\right)$, with significant differences among the three classes for both parameters (all $p$ values from the multiple comparison tests $<0.05$ ). 


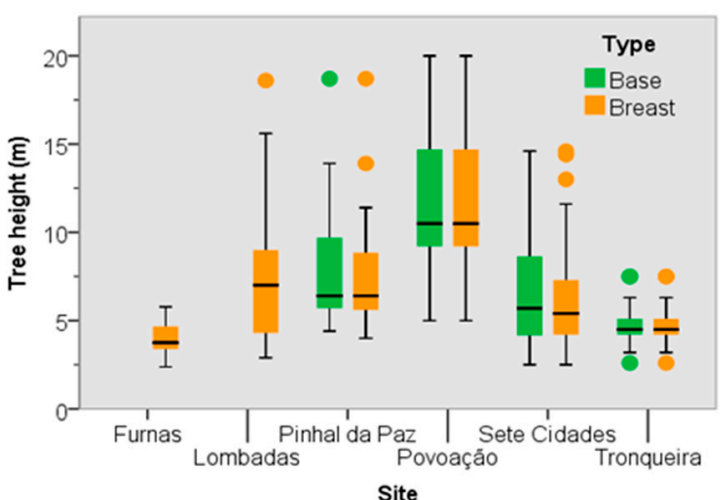

(a)

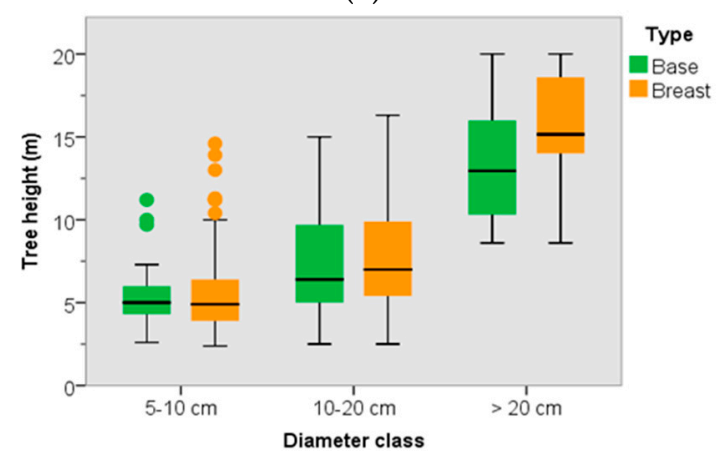

(d)

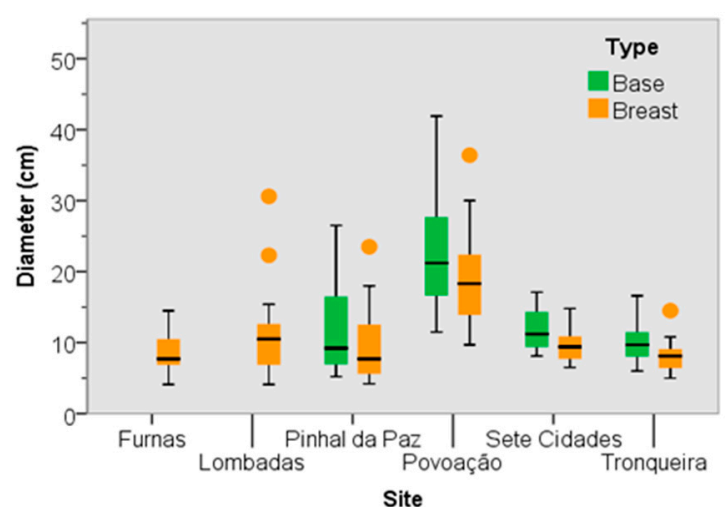

(b)

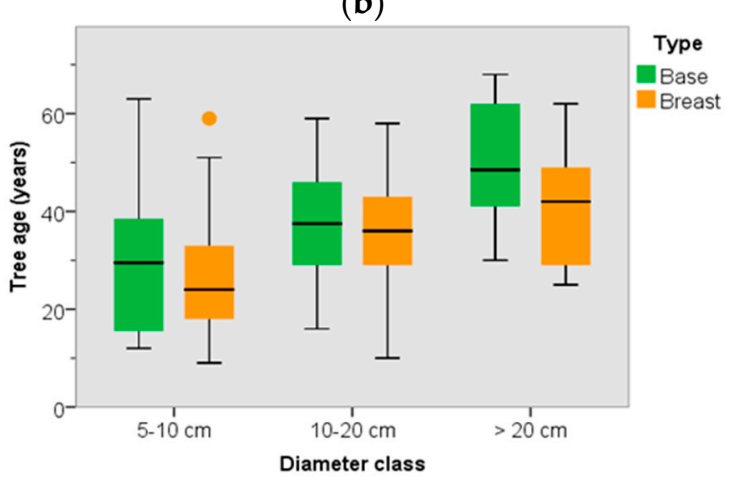

(e)

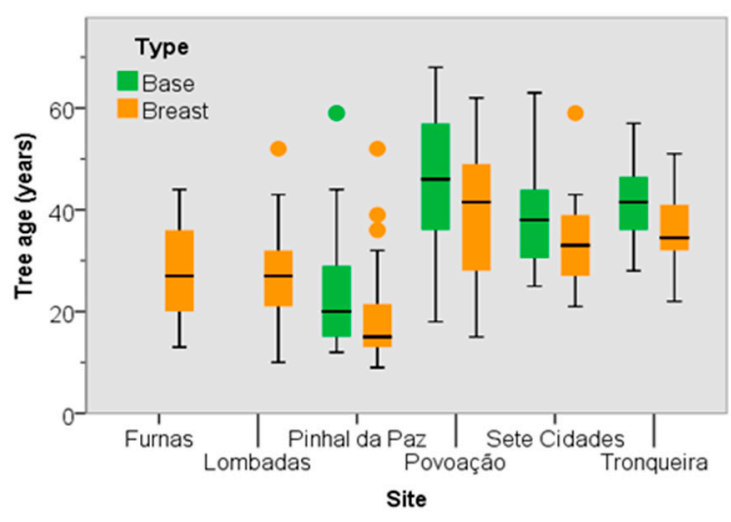

(c)

Figure 6. First row: Distribution of tree height (a), trunk diameter $(\mathbf{b})$ and tree age (c) for each sampled stand in São Miguel Island. Second Row: Distribution of tree height (d) and estimated tree ages (e) by diameter class $(<10,10-20,>20 \mathrm{~cm}$ ). From a total of 256 samples of L. azorica (Seub.) Franco collected in São Miguel Island, collected at breast height (130 cm above substrate) or at tree base $(20 \mathrm{~cm}$ above substrate). In the boxplots, circles represent outliers. 


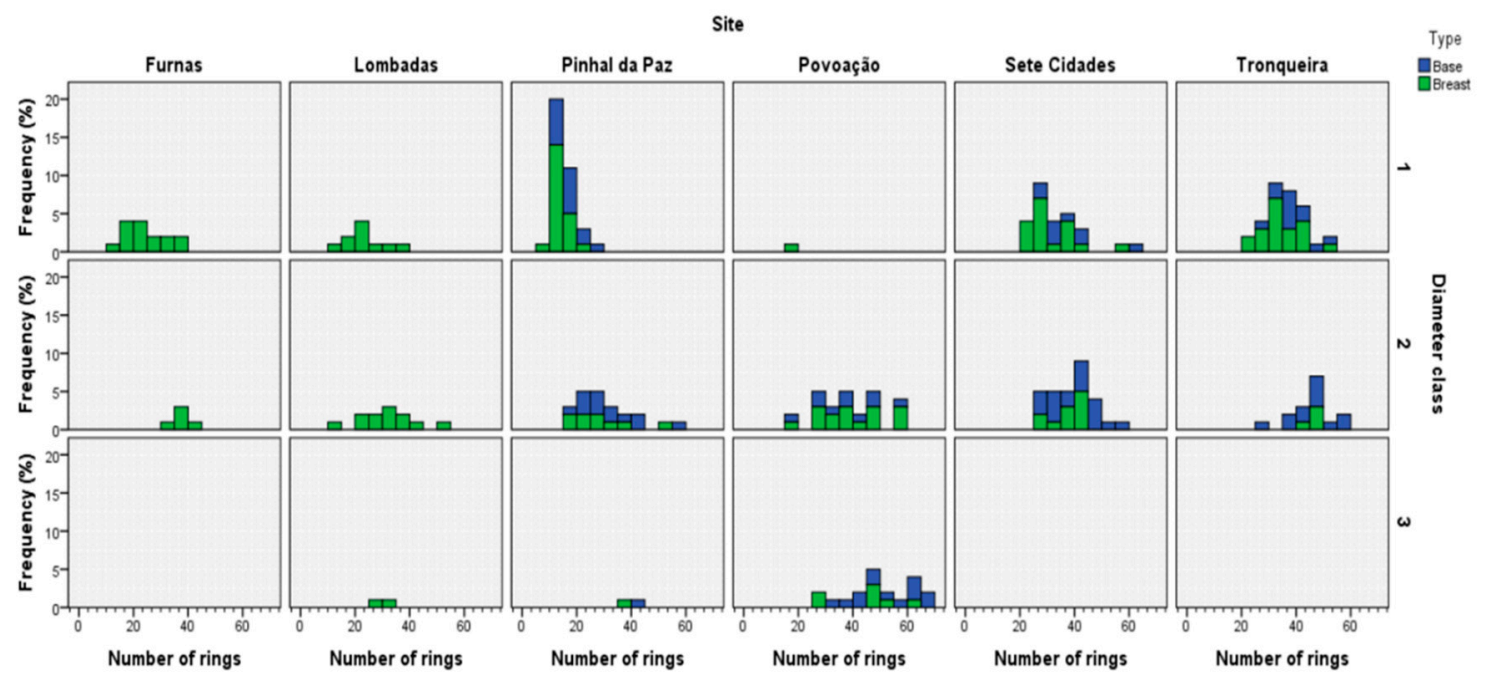

Figure 7. Distribution of the cambial age of L. azorica (Seub.) Franco trees obtained at six sites in São Miguel Island. The chart allows to appreciate the age and size structure of the different populations. Diameter classes (cm): (1,<10; 2, 10-20; 3, >20 cm).

\subsection{Tree Age and Dendrometric Traits}

Scatter plots show a correlation between tree age and trunk diameter, although with some variation between sites (Figure 8). The multiple linear regression models showed a reduced fit when we tested for the entire sample, both for diameter at breast height and at the base (a selection of models is shown in Table 2 and Figure 9), both with or without log transformation, with a significant number of observations far from the regression predicted value, and a high residual error (see Table S1 for the full list of tested models). Not all tested models showed significant regression coefficients $(p<0.05)$.

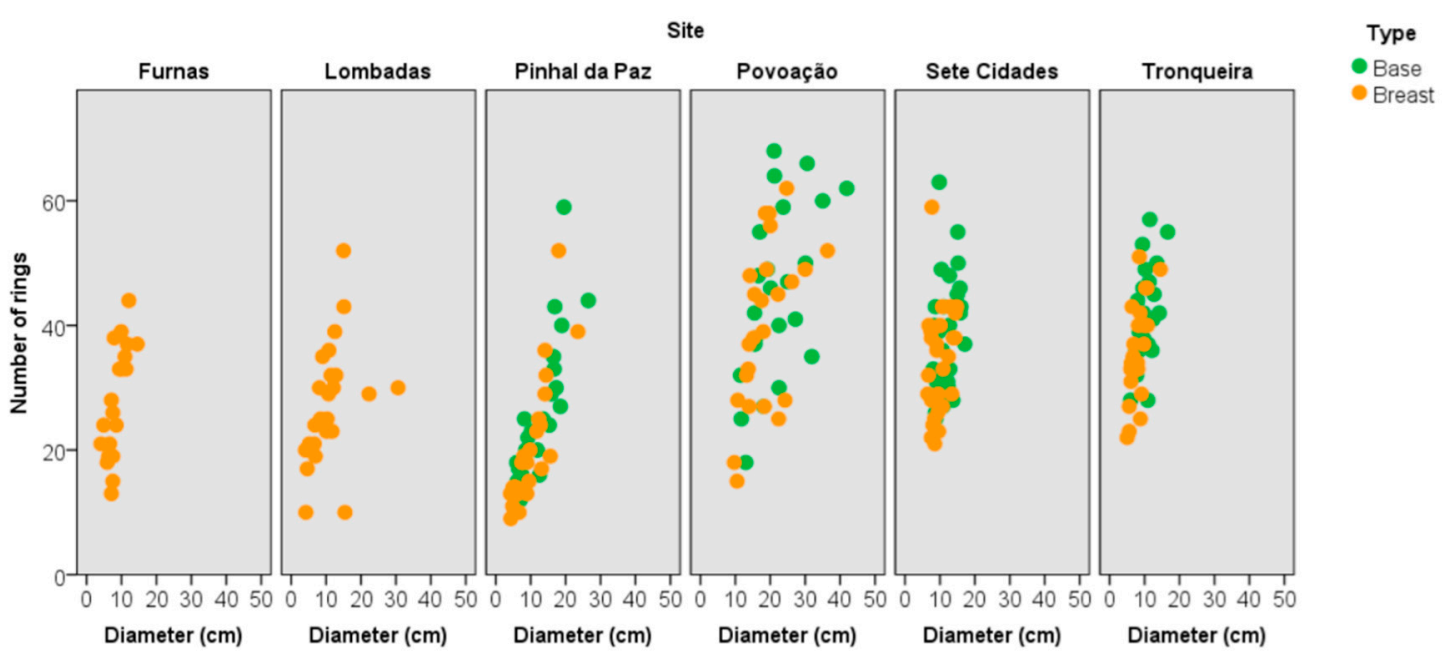

Figure 8. Scatter plots representing the relationship between estimated tree age and trunk diameter at base and at breast height, for six stands of L. azorica (Seub.) Franco in São Miguel Island.

Separate regressions were calculated for each stand (a selection of models is shown in Table 2 and Figure 9), showing an increase in the $R^{2}$ value, particularly for Pinhal da Paz. Dendrometric parameters also showed a better predictive ability to estimate tree age for several stands when outliers were removed from the data set, namely for Lombadas, Achada das Furnas and Tronqueira (a selection of models is shown in Table 2 and Figure 9). The full set of tested models for each stand, and with or without outliers are shown in Tables S2-S7. 

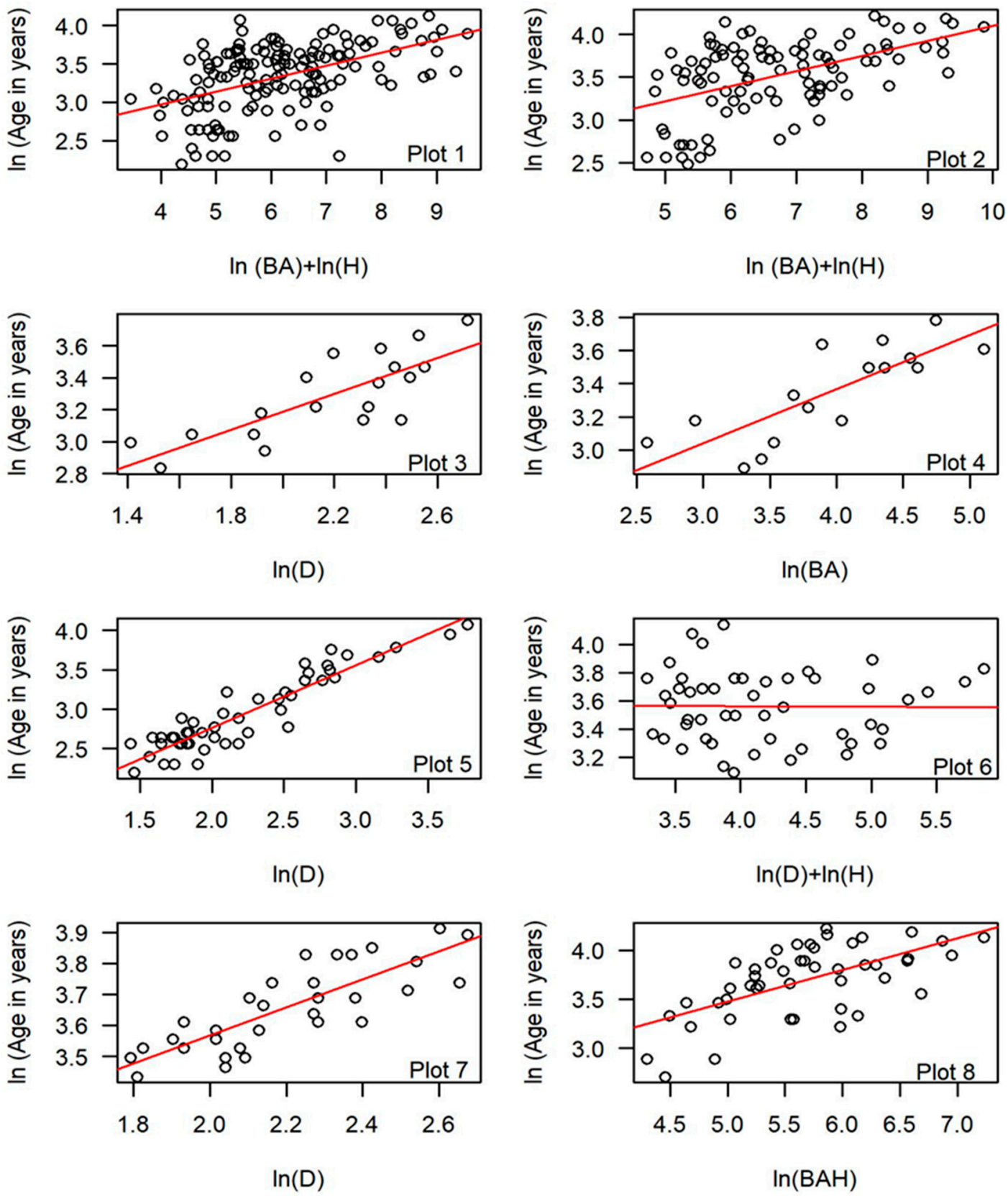

Figure 9. Scatter plots of the allometric equations used to predict L. azorica (Seub.) Franco age from dendrometric traits (BA, Basal Area; D, Diameter at Breast Heigth; H, Maximun Tree Height) Comparison of models for all the available samples at breast height, (plot 1, as defined in Table 2), at tree base (plot 2, as defined in Table 2) and for each stand (plots $\mathbf{3 - 8}$, as defined in Table 2). This is a selection of the best models. See Table 2 and Tables S1-S7 for the full set of tested models. 
Table 2. Selected allometric equations relating tree age and dendrometric parameters tested for $147 \mathrm{~L}$. azorica (Seub.) Franco trees sampled at breast height (BH), for 97 L. azorica trees sampled at base (Base), and for each stand of L. azorica in São Miguel Island. Allometric models: * [54]; ** [2]; *** Current study. Regression model equation (see Tables S1-S7); Stand code (see Table 1). N (number of samples). Plot \# (see Figure 9). Adjusted determination coefficient (Adj $R^{2}$ ); Akaike Information Criterion (AIC); Root Mean Square Error (RMSE); Mean Relative Error (MRE); Correction Factor (CF); Diameter (D); Tree Height $(\mathrm{H})$; Basal Area (BA). This is a selection of the best models. See Tables S1-S7 for the full set of tested models.

\begin{tabular}{|c|c|c|c|c|c|c|c|c|c|}
\hline Stand & BH/Base & $N$ & Plot $\#$ & Regression Model & $\operatorname{Adj} R^{2}$ & AIC & RMSE & MRE & $\mathrm{CF}^{\# \#}$ \\
\hline All & $\mathrm{BH}$ & 147 & & $\ln (A g e)=a+b_{1} \ln (D)+\varepsilon^{*}$ & 0.34 & 118.60 & 10.01 & -0.07 & 1.07 \\
\hline All & $\mathrm{BH}$ & 147 & & $\ln (A g e)=a+b_{1} \ln (D)+b_{2} \ln (H)+\varepsilon^{* * *}$ & 0.38 & 110.29 & 10.05 & -0.06 & 1.06 \\
\hline All & $\mathrm{BH}$ & 147 & 1 & $\begin{array}{c}\ln (\text { Age })=a+b_{1} \ln (B A)+b_{2} \ln (H)+\varepsilon^{* *} \\
\text { Null Model }\end{array}$ & 0.39 & $\begin{array}{l}106.87 \\
178.18\end{array}$ & 9.75 & -0.06 & 1.06 \\
\hline All & Base & 97 & & $\ln (A g e)=a+b_{1} \ln (D)+\varepsilon^{*}$ & 0.36 & 74.47 & 11.60 & -0.06 & 1.06 \\
\hline All & Base & 97 & & $\ln (A g e)=a+b_{1} \ln (D)+b_{2} \ln (H)+\varepsilon^{* * *}$ & 0.41 & 67.46 & 11.70 & -0.06 & 1.06 \\
\hline All & Base & 97 & 2 & $\begin{array}{c}\ln (\text { Age })=a+b_{1} \ln (B A)+b_{2} \ln (H)+\varepsilon^{* *} \\
\text { Null Model }\end{array}$ & 0.44 & $\begin{array}{c}62.31 \\
116.37\end{array}$ & 11.12 & -0.05 & 1.05 \\
\hline $\mathrm{LO}$ & $\mathrm{BH} /$ Base & 19 & 3 & $\ln (A g e)=a+b_{1} \ln (D)+\varepsilon^{*}$ & 0.61 & -11.26 & 4.41 & -0.01 & 1.01 \\
\hline $\mathrm{AF}$ & $\mathrm{BH} /$ Base & 16 & 4 & $\ln (A g e)=a+b_{1} \ln (B A)+\varepsilon^{* * *}$ & 0.62 & -6.82 & 4.63 & -0.01 & 1.01 \\
\hline PP & $\mathrm{BH} /$ Base & 49 & 5 & $\ln (A g e)=a+b_{1} \ln (D)+\varepsilon^{*}$ & 0.86 & -22.87 & 3.92 & -0.02 & 1.02 \\
\hline SC & $\mathrm{BH} /$ Base & 49 & 6 & $\ln (A g e)=a+b_{1} \ln (D)+b_{2} \ln (H)+\varepsilon^{* * *}$ & 0.13 & 1.76 & 8.60 & -0.03 & 1.03 \\
\hline TR & $\mathrm{BH} /$ Base & 33 & 7 & $\ln (A g e)=a+b_{1} \ln (D)+\varepsilon^{*}$ & 0.66 & -69.53 & 3.12 & -0.03 & 1.00 \\
\hline $\mathrm{PO}$ & $\mathrm{BH} /$ Base & 47 & 8 & $\ln (A g e)=a+b_{1} \ln (B A H)+\varepsilon^{* * *}$ & 0.40 & 17.78 & 10.77 & -0.04 & 1.04 \\
\hline
\end{tabular}

Note: \# All Equations included significant regression coefficients $(p<0.05)$; All equations before application of Correction Factor-See Supplementary Material for BH and base samples (Table S1) and for each stand (Tables S2-S7). Models indicated in bold were tested after removing the outliers. \#\# Correction factor to remove the bias of regression estimates for logarithmic transformed data.

\subsection{Estimated Annual Increment}

For 101 pairs of base and breast height cores collected at Pinhal da Paz, Povoação, Sete Cidades and Tronqueira, estimated tree age differences between breast and base height were concentrated between 3 and 7 years, with an estimated average of 5 years to reach breast height. Thus, annual radial growth rate was estimated by periodic annual increment, with an average of $0.68 \mathrm{~cm} \cdot y e a r^{-1}$, and with a concentration of values between 0.300 and $0.833 \mathrm{~cm} \cdot \mathrm{year}^{-1}$ (Table 3).

Table 3. Descriptive statistics estimated for periodic annual increment and tree age difference, from 101 pairs of L. azorica (Seub.) Franco wood cores collected at tree base and at breast height.

\begin{tabular}{cccccc}
\hline Growth Parameters & Mean & Standard Deviation & Standard Error & Minimum & Maximum \\
\hline PAI (cm.year ${ }^{-1}$ ) & 0.679 & 0.659 & 0.066 & 0.033 & 4.200 \\
Age Diference (years) & 5.010 & 3.413 & 0.340 & 0.000 & 18.000 \\
\hline
\end{tabular}

\section{Discussion}

\subsection{Laurel Forest in São Miguel Island}

The future of the natural vegetation is seriously threatened by non-indigenous plants already considered as problematic in the Azores [15]. Invasive plants were commonly found at all the sites, the most threatened stands being Sete Cidades and Pinhal da Paz, where P. undulatum Vent. and H. gardnerianum Sheppard ex Ker-Gawl., two top invasive species $[4,58]$ are very abundant; but also in Lombadas, where the latter is also common. Moreover, the area of natural forest on this island has been reduced [12], presently corresponding to small fragmented remains in the western part, and to larger stands in the central and eastern areas, which is reflected in the collected data (see Figure 1). More than $75 \%$ of the tree trunks were more than 20 years old, about $60 \%$ were between 25 and 50 years old, and only about $15 \%$ were more than 50 years old. This might suggest the existence of a secondary forest that is probably more recent at Achada das Furnas, Lombadas and Pinhal da Paz, due to human disturbance [59] and somewhat older at Povoação, Sete Cidades and Tronqueira. At Tronqueira and 
Povoação stands, we found what appears to be older remains of a laurel forest with a general higher density/cover of endemic tree species. The taller, larger and older individuals in this study where found at Povoação, which suggests that a larger forest might have occurred there, in the past, presently restricted to water stream margins, a mesic submontane forest described by Elias et al. [12]. At higher altitudes, such as in Tronqueira, we found as invasive species mostly H. gardnerianum and C. arborea Aiton, and the dominant native trees often corresponded to Juniperus brevifolia (Seub.) Antoine or Ilex perado subsp. azorica (Loes.) Tutin. Therefore, the vegetation at higher elevation corresponded more to a Juniperus Montane Woodland [12]. The dense canopies of old L. azorica and J. brevifolia trees serve as protection for a wide variety of species, characteristic of the Azores natural forests, providing shelter and creating microhabitats $[9,60]$, those species allow the recovery of other native woody species and the restoration of the natural forests [18].

\subsection{Growth Ring Anatomy}

The seasonality of the Azorean climate, temperate with mild summers, never too dry, allows the differentiation of earlywood and latewood in secondary xylem, which we think is mostly influenced by precipitation rate variations [61]. As shown in the results, in L. azorica (Seub.) Franco) increment cores, there was a progressive color differentiation between earlywood, lighter, and latewood, darker, particularly at the ring boundary. There was no visible distinct heartwood in any of the taken increment cores, since no color change or difference in light transmission could be observed along the increment fresh cores, immediately after being taken, confirming earlier Laurus observations by [21,62].

In São Miguel Island we found a diffuse-porous wood structure in L. azorica, as reported for L. novocanariensis Rivas Mart., Lousã, Fern.Prieto, E.Días, J.C.Costa \& C.Aguiar from Tenerife by Morales et al. [21]. According to those authors, vessel distribution in the wood of Laurus suggests a high efficiency. While relatively small, xylem vessels are present at high density, requiring a much smaller functional xylem cross-section to supply an equivalent leaf area, than either diffuse porous angiosperms or conifers. Cermák et al. [29] also related L. azorica to Quercus as ring-porous species. The wood structure of L. azorica in São Miguel is very close to the description provided for Tenerife, increasing survival in adverse environmental conditions, such as highly exposed locations, and from wet places to almost dry lava flows [9]. Meanwhile, in species with a random distribution of vessels, this often obscures the ring boundaries, making ring identification in diffuse porous genera particularly difficult [5]. However, L. azorica showed distinct growth rings as found for other Lauraceae, including the close relative, Laurus nobilis L. $[21,27,30]$. The greater difficulties found in L. azorica growth ring analysis corresponded to ring anomalies which can be originated by reaction wood, knots, compartmentalization by fungi or putrefaction, observed in the pith, and mainly in larger individuals.

According to Worbes [50] tree ring typology, the growth rings of the Lauraceae show no distinct boundary between latewood and earlywood, but just a thickening of the cell wall and a reduction of the cell lumen from earlywood to latewood. Reis-Avila and Oliveira [30] reported that growth rings in the Lauraceae generally include a boundary marked by an abrupt transition between thick-walled and radially flattened fibers in latewood of a ring, and thin-walled earlywood fibers of the consecutive ring; or otherwise a marginal parenchyma band delimiting tree-rings. Our results indicate a transition from earlywood to latewood, with an increase in cell wall thickness and a decrease in cell lumen, but also of what appears to be a fibrous boundary marking the transition from latewood to earlywood, evident in our micrographs due to the different coloration and extreme flatness of the fibers. The marked boundary between annual growth rings observed in this species is typical of some genera with diffuse porous wood, and could be formed by marginal parenchyma cells [5] or delimited by a fibrous zone [63]. Because of the visible red stained, thick-walled cells, observed at the growth ring boundary, L. azorica seems to have ring boundaries delimited by radially flattened latewood fibers, also present in other Laurus species $[63,64]$. However, those fibers show a peculiar affinity for Astrablue, what could indicate the presence of polysaccharides residues from the cell wall, such as cellulose and pectins [65]. 
We noticed that some modifications occur in L. azorica as it gets older, as in other trees, a continuous and progressive decrease in tree ring amplitude tends to happen [63]. The observed width of tree rings showed high variability, between and in the same increment, reflecting the influence of the environmental factors in the growth rate, namely available light, temperature and water [66].

Several xylem rays where visible, perpendicular to the ring boundaries, a trait that is very prominent in hardwoods, providing radial transportation functions [67]. Laurus azorica secondary xylem showed strict radial regularities, as found in Tenerife for L. novocanariensis [21]. As a hardwood species, L. azorica xylem vessels show very evident pits in tangential section, which allows for water transport between individual vessels. Reddish cells, identified in several cross-sections, randomly distributed in the xylem, could correspond to tylosis with simple piths or oil cells associated with rays, since both structures have been observed in Laurus $[63,64]$.

\subsection{Dendrometry and Dendrochronology}

We explored the allometric relationship between tree age (ring counts) and various dendrometric traits in L. azorica (Seub.) Franco, since the number of growth rings can be used as a good estimate of stand age [2,68]. Although tree growth is the result of very complex processes [69], allometric models can be a robust alternative to predict the growth and the mean age of tree populations [70]. Furthermore, models relating tree age and other dendrometric variables are available for different species and different geographic areas (e.g., [2-4,54,55]). We analyzed model fit for the entire data set and also separately, according to the sampled stands [2,3,54]. When modeling the global data set, regression models explaining tree age based on trunk diameter, basal area, and/or tree height, were of low quality, in contrast with the results previously obtained by Borges Silva et al. [2,4] for the invasive tree P. undulatum Vent. in the Azores. For L. azorica, model adjustment clearly increased when modelling separately for each stand, emphasizing the possible importance of local factors (e.g., soil type; microclimatic conditions), leading to a greater predictive ability at a site-specific level (e.g., $[55,71])$. While the climate in the Azores is somewhat homogeneous, a relevant change in the climatic conditions is to be expected with elevation, corresponding to a decrease in temperature and to an increase in precipitation and relative humidity [32], as shown in the physical characterization of our study sites. In fact, pronounced climatic differences were found between the stands, particularly regarding annual precipitation, with annual values ranging from about 2100 to $1300 \mathrm{~mm}$. Therefore, implementing allometric equations beyond the specific site for which they were developed can affect estimate accuracy [2,72]. Moreover, assuming that the collection of as many samples per tree as possible, in a large number of trees per site, would reduce the level of environmental noise, it might still be possible to improve the fit of the allometric models for this species [73].

The present study suggests that if diameter at breast height is available, a relative simple equation could be used to predict tree age. Trunk diameter is often the best predictor for age in allometric models, because both variables are strongly correlated [74], it is a relatively easy and inexpensive measurement to obtain, and is often available in forest inventory data [75]. In fact, growth estimates of forest trees are typically made by using measurements of diameter at breast height and of total height, which are scaled to the whole tree via allometric equations derived from destructive sampling $[4,76]$. Age of L. azorica trees was also closely correlated with tree height and basal area [77], and our results revealed that, in some cases, models with cubic terms improved age estimates $[2,4,53,54]$, although the performance of simpler models, including only a linear effect, was also acceptable [2,4].

In this research, samples taken at tree base and at breast height allowed to estimate an average radial growth rate of $0.68 \mathrm{~cm} \cdot y^{-1} \mathrm{r}^{-1}$, with an estimated average of 5 years to reach breast height. A higher growth rate than the values reported for the widespread invasive species $P$. undulatum, with a radial growth rate of $0.38 \mathrm{~cm} \cdot$ year $^{-1}$, and an average of 8 years needed to attain breast height [2,4]. Therefore, other factors might be affecting growth and dispersal of those species, and a local comparison of growth rates would be needed, if the invasion process is to be better understood, since growth rate can provide a general representation of the growth dynamics at certain conditions (climate, hydrology, 
soil, and successional stages) [78]. These analyses are essential to support the sustainable management and conservation of natural forests [78].

\section{Conclusions}

As for other Lauraceae, L. azorica (Seub.) Franco has shown a promising potential for dendrochronology studies [30]. We showed that increment cores can be successfully used to estimate tree age, without the need to cut L. azorica trees. Moreover, age-diameter relationships can be further validated by increasing sample size and extending the sampling effort to other islands, where laurel forests are still present [12]. In the Azores, dendrochronology can become a helpful tool to evaluate current and future threats to forests, and support forest management, through the comparison of indigenous and non-indigenous trees, and the future integration of climatic parameters. If long chronologies are not available, at least tree age and growth rate can be estimated and related with environmental variables, improving L. azorica niche definition. Moreover, older specimens could eventually be found in other islands, such as Terceira and Pico, where larger stands of natural forests are still present.

Supplementary Materials: The following are available online at http://www.mdpi.com/1999-4907/10/7/538/s1. Table S1: Allometric equations tested for 147 and 97 Laurus azorica (Seub.) Franco trees sampled respectively at breast height $(\mathrm{BH})$ and at base in São Miguel Island. Allometric models: * [54]; ${ }^{* *}$ [2]; ** Current study. Regression model equations; Null Model $\left(\mathrm{M}_{0}\right)$; Adjusted determination coefficient (Adj $\left.R^{2}\right)$; Akaike Information Criterion (AIC); Root Mean Square Error (RMSE); Mean Relative Error (MRE), Correction Factor (CF). Diameter (D); Tree Height (H); Basal Area (BA); Table S2: Allometric equations tested for 25 Laurus azorica (Seub.) Franco trees (ALL) and for 19 samples (without outliers, WO) of Laurus azorica trees from Lombadas, São Miguel Island. Allometric models: ${ }^{*}[54] ;{ }^{* *}[2] ;{ }^{* * *}$ Current study. Regression model equations; Null Model $\left(\mathrm{M}_{0}\right)$; Adjusted determination coefficient (Adj $R^{2}$ ); Akaike Information Criterion (AIC); Root Mean Square Error (RMSE); Mean Relative Error (MRE), Correction Factor (CF). Diameter (D); Tree Height (H); Basal Area (BA); Table S3: Allometric equations tested for 20 Laurus azorica (Seub.) Franco trees (ALL) and for 16 samples (without outliers, WO) of Laurus azorica trees from Achada das Furnas, São Miguel Island. Allometric models: * [54]; ${ }^{* *}[2] ;{ }^{* * *}$ Current study. Regression model equations; Null Model $\left(\mathrm{M}_{0}\right)$; Adjusted determination coefficient (Adj $\left.R^{2}\right)$; Akaike Information Criterion (AIC); Root Mean Square Error (RMSE); Mean Relative Error (MRE), Correction Factor (CF). Diameter (D); Tree Height (H); Basal Area (BA); Table S4: Allometric equations tested for 49 Laurus azorica (Seub.) Franco trees from Pinhal da Paz, São Miguel Island. Allometric models: * [54]; ** [2]; *** Current study. Regression model equations; Null Model $\left(\mathrm{M}_{0}\right)$; Adjusted determination coefficient (Adj $\left.R^{2}\right)$; Akaike Information Criterion (AIC); Root Mean Square Error (RMSE); Mean Relative Error (MRE), Correction Factor (CF). Diameter (D); Tree Height (H); Basal Area (BA); Table S5: Allometric equations tested for 49 Laurus azorica (Seub.) Franco trees from Sete Cidades, São Miguel Island. Allometric models: * [54]; ${ }^{* *}$ [2]; ${ }^{* * *}$ Current study. Regression model equations; Null Model $\left(\mathrm{M}_{0}\right)$; Adjusted determination coefficient (Adj $R^{2}$ ); Akaike Information Criterion (AIC); Root Mean Square Error (RMSE); Mean Relative Error (MRE), Correction Factor (CF). Diameter (D); Tree height (H); Basal area (BA); Table S6: Allometric equations tested for 48 Laurus azorica (Seub.) Franco trees (ALL) and for 33 samples (without outliers, WO) of Laurus azorica trees from Tronqueira, São Miguel Island. Allometric models: ${ }^{*}$ [54]; ${ }^{* *}$ [2]; ${ }^{* * *}$ Current study. Regression model equations; Null Model $\left(\mathrm{M}_{0}\right)$; Adjusted determination coefficient (Adj $\left.R^{2}\right)$; Akaike Information Criterion (AIC); Root Mean Square Error (RMSE); Mean Relative Error (MRE), Correction Factor (CF). Diameter (D); Tree Height (H); Basal Area (BA); Table S7: Allometric equations tested for 47 Laurus azorica (Seub.) Franco trees from Povoação stand, São Miguel Island. Allometric models: * [54]; ${ }^{* *}$ [2]; ${ }^{* * *}$ Current study. Regression model equations; Null Model $\left(\mathrm{M}_{0}\right)$; Adjusted determination coefficient (Adj $\left.R^{2}\right)$; Akaike Information Criterion (AIC); Root Mean Square Error (RMSE); Mean Relative Error (MRE), Correction Factor (CF). Diameter (D); Tree Height (H); Basal Area (BA).

Author Contributions: B.M., L.B.S. and L.S. designed the study, performed the fieldwork, assisted labwork, analyzed the data and prepared a first draft of the manuscript. R.C. and A.S.R. supervised and performed most of the wood anatomical work. R.R. and M.C. assisted with the fieldwork and with data preparation and analysis. All the authors participated in the discussion and revision of the manuscript.

Funding: This research was funded by: Project FOREST-ECO ${ }^{2}$-Towards an Ecological and economic valorization of the Azorean Forest ACORES-01-0145-FEDER-000014-Azores 2020 PO, 2016-2019; FEDER funds through the Operational Programme for Competitiveness Factors-COMPETE and by National Funds through FCT-Foundation for Science and Technology under the UID/BIA/50027/2019 and POCI-01-0145-FEDER-006821; DRCT-M1.1.a/005/Funcionamento-C-/2019 (CIBIO-A), Secretaria Regional do Mar, Ciência e Tecnologia, Governo dos Açores; and by MC-Apoio à edição de publicações científicas 2019 PRO-SCIENTIA-Eixo 3-QUALIFICAR-Ação/Medida 3.3. b-“Incentivar a produção, formação e divulgação científica especializada"-Apoio à edição de publicações científicas (03.3.c.2019 (SRMCT/DRCT), Governo Regional dos Açores). 
Acknowledgments: We thank Ana Balibrea for support in the acquisition of macroscopic photos. We thank Direção Regional dos Recursos Florestais, for permission to sample in Pinhal da Paz.

Conflicts of Interest: The authors declare no conflict of interest.

\section{References}

1. Grebner, D.L.; Bettinger, P.; Siry, J.P. Introduction to Forestry and Natural Resources; Academic Press: Cambridge, MA, USA, 2013; p. 496.

2. Borges Silva, L.; Teixeira, A.; Alves, M.; Elias, R.B.; Silva, L. Tree age determination in the widespread woody plant invader Pittosporum undulatum. For. Ecol. Manage. 2017, 400, 457-467. [CrossRef]

3. Borges Silva, L.; Lourenço, P.; Bicudo, N.; Alves, M.; Elias, R.B.; Medeiros, V.; Silva, L. Development of Allometric Equations for Estimating Above-Ground Biomass of Woody Plant Invaders: The Case of Pittosporum undulatum in the Azores Archipelago. In International Conference on Dynamics, Games and Science; Springer: Cham, Switzerland, 2014; pp. 463-484.

4. Borges Silva, L.; Lourenço, P.; Teixeira, A.; Azevedo, E.B.; Alves, M.; Elias, R.B.; Silva, L. Biomass valorization in the management of woody plant invaders: The case of Pittosporum undulatum in the Azores. Biomass Bioenergy 2018, 109, 155-165. [CrossRef]

5. Speer, J. Fundamentals of Tree-Ring Research; University of Arizona Press: Tucson, AZ, USA, 2010.

6. Barry, D. Refining Dendrochronology to Evaluate the Relationship between Age and Diameter for Dominant Riparian Trees in the Redwood Creek Watershed. Master's Thesis, University of San Francisco, San Francisco, CA, USA, 2014. Available online: https://repository.usfca.edu/capstone/27 (accessed on 1 April 2017).

7. Fraver, S.; Bradford, J.B.; Palik, B.J. Improving tree age estimates derived from increment cores: A case study of red pine. For. Sci. 2011, 57, 164-170.

8. Maxwell, R.S.; Wixom, J.A.; Hessl, A.E. A comparison of two techniques for measuring and crossdating tree rings. Dendrochronologia 2011, 29, 237-243. [CrossRef]

9. Dias, E.; Elias, R.B.; Melo, C.; Mendes, C. O elemento insular na estruturação das florestas da Macaronésia. Açores e Madeira-A floresta das ilhas 2007, 6, 15-48.

10. Elias, R.B.; Dias, E. Ecologia das florestas de Juniperus dos Açores. Cadernos de Botânica $n^{\circ}$ 5; Herbário da Universidade dos Açores, Angra do Heroísmo: Azores, Portugal, 2008.

11. Silva, L.; Moura, M.; Schaefer, H.; Rumsey, F.; Dias, E.F. Vascular Plants (Tracheobionta). In $A$ List of the Terrestrial and Marine Biota from the Azores; Borges, P.A.V., Costa, A., Cunha, R., Gabriel, R., Gonçalves, V., Martins, A.F., Melo, I., Parente, M., Raposeiro, P., Rodrigues, P., et al., Eds.; Princípia: Cascais, Portugal, 2010; pp. 117-146.

12. Elias, R.B.; Gil, A.; Silva, L.; Fernández-Palacios, J.M.; Azevedo, E.B.; Reis, F. Natural zonal vegetation of the Azores Islands: Characterization and potential distribution. Phytocoenologia 2016, 46, 107-123. [CrossRef]

13. Borges, P.A.V.; Azevedo, E.B.; Borba, A.; Francisco, O.D.; Gabriel, R.; Silva, E. Ilhas Oceânicas. In Ecossistemas e Bem Estar Humano: Avaliação para Portugal do Millennium Ecossystem Assessment; Pereira, H.M., Domingos, T., Vicente, L., Eds.; Escolar Editora: Lisboa, Portugal, 2009; pp. 463-510.

14. Ferreira, M.T.; Cardoso, P.; Borges, P.A.V.; Gabriel, R.; de Azevedo, E.B.; Reis, F.; Araújo, M.B.; Elias, R.B. Effects of climate change on the distribution of indigenous species in oceanic islands (Azores). Clim. Chang. 2016, 138, 603-615. [CrossRef]

15. Silva, L.; Smith, C. A quantitative approach to the study of non-indigenous plants: An example from the Azores Archipelago. Biodivers. Conserv. 2006, 15, 1661-1679. [CrossRef]

16. Silva, L.; Martins, M.; Maciel, G.; Moura, M. Flora Vascular dos Açores. Prioridades em Conservação. Azorean Vascular Flora. Priorities in Conservation; Amigos dos Açores \& CCPA: Ponta Delgada, Portugal, 2009; p. 116.

17. Costa, H.; Bettencourt, M.J.; Silva, C.M.N.; Teodósio, J.; Gil, A.; Silva, L. Invasive Alien Plants in the Azorean Protected Areas: Invasion Status and Mitigation Actions. In Plant Invasions in Protected Areas; Springer: Dordrecht, The Netherlands, 2013; pp. 375-394. [CrossRef]

18. DRRF. Plano de Gestão Florestal do Perímetro Florestal e Matas Regionais da Ilha de São Miguel; Secretaria Regional da Agricultura e Florestas, Região Autónoma dos Açores: Ponta Delgada, Portugal, 2017.

19. Silva, L.; Beech, E. Laurus Azorica. The IUCN Red List of Threatened Species 2017: e. T38397A81868030; IUCN Global Species Programme Red List Unit: Cambridge, UK, 2017. [CrossRef] 
20. Viera, J.; Campelo, F.; Nabais, C. Dendrochronology of maritime pine in the middle of the Atlantic Ocean. Dendrochronologia 2017, 45, 73-80. [CrossRef]

21. Morales, D.; Jiménez, M.S.; González-Rodríguez, A.M.; Cermák, J. Laurel forests in Tenerife, Canary islands: I Xylem structure in stems and petioles of Laurus azorica trees. Trees 2002, 16, 529-537. [CrossRef]

22. Gaspar, C.; Borges, P.A.V.; Gaston, K.J. Diversity and distribution of arthropods in native forests of the Azores archipelago. Arquipélago. Life Mar. Sci. 2008, 25, 1-30.

23. Rivas-Martínez, S.; Díaz, T.E.; Fernández-González, F.; Izco, J.; Loidi, J.; Lousã, M.; Penas, A. Vascular plant communities of Spain and Portugal: Addenda to the syntaxonomical checklist of 2001. Itinera Geobotanica 2002, 15, 5-922.

24. Rodríguez-Sánchez, F.; Guzmán, B.; Alfredo Valido, A.; Vargas, P.; Juan Arroyo, J. Late Neogene history of the laurel tree (Laurus L., Lauraceae) based on phylogeographical analyses of Mediterranean and Macaronesian populations. J. Biogeog. 2009, 36, 1270-1281. [CrossRef]

25. Moura, M.; Vieira, A.; Silva, L. Determination of the Possible Presence of Hybrids of Ilex azorica and Laurus azorica with Congener Exotic Taxa in the Target Area of the Project "Terras do Priolo"_LIFE12 NAT/PT/000527; Final Report; InBIO, CIBIO-Açores, Departamento de Biologia, Universidade dos Açores: Ponta Delgada, Portugal, 2015; p. 15.

26. Vieira, A.F.; Moura, M.; Silva, C.; Silva, L. Screening for potential hybrids reveals new insights about Laurus phylogeography in the Azores. In Conference Program and Abstracts of the 2nd International Conference on Island Evolution, Ecology and Conservation: Island Biology 2016, 18-22 July 2016, Angra do Heroísmo, Azores, Portugal. Arquipelago. Life and Marine Sciences; Gabriel, R., Elias, R.B., Amorim, I.R., Borges, P.A.V., Eds.; University of the Azores: Ponta Delgada, Portugal, 2016; p. 505.

27. Câmara, M. Estimativa das idades das árvores numa floresta natural invadida na Ilha de São Miguel, Açores. Master's Thesis, Departamento de Biologia, Universidade dos Açores, Ponta Delgada, Portugal, 2016; p. 23. Available online: https://repositorio.uac.pt/handle/10400.3/4042 (accessed on 12 June 2018).

28. Rego, R.; Borges Silva, L.; Medeiros, F.; Porteiro, J.; Silva, L. Ecological Characterization as the First Step Towards the Conservation of Natural Unprotected Areas: A case Study in the Azores. In Proceedings of the European Meeting of Phytosociology, Biogeography and Syntaxonomy of the Atlantic Regions, University of Cape Verde, Praia, Cape Verde, 5-7 November 2017.

29. Cermák, J.; Jiménez, M.S.; González-Rodríguez, A.M.; Morales, D. Laurel forests in Tenerife, Canary Islands. II. Efficiency of the water conducting system in Laurus azorica trees. Trees 2002, 16, 538-546. [CrossRef]

30. Reis-Avila, G.; Oliveira, J.M. Lauraceae: A promising family for the advance of neotropical dendrochronology. Dendrochronologia 2017, 44, 103-116. [CrossRef]

31. Forjaz, V.H.; Tavares, J.M.; Azevedo, E.M.V.B.; Nunes, J.C.; Santos, R.S.; Barreiros, J.P.; Gallagher, L.; Barcelos, P.J.M.; Silva, P.H.; Cardigos, F.; et al. Atlas Básico dos Açores; Forjaz, V.H., Ed.; Observatório Vulcanológico dos Açores: Ponta Delgada, Portugal, 2014; p. 112.

32. Azevedo, E. Condicionantes dinâmicas do clima do Arquipélago dos Açores. Elementos para o seu estudo. Açoreana 2001, 9, 309-317.

33. Monteiro, R.; Furtado, S.; Rocha, M.; Freitas, M.; Medeiros, R.; Cruz, J.V. O Ordenamento do Território nos Açores: Política e Instrumentos; Secretaria Regional do Ambiente e do Mar, Direcção Regional do Ordenamento do Território e dos Recursos Hídricos: Ponta Delgada, Portugal, 2008.

34. Lourenço, P.; Medeiros, V.; Gil, A.; Silva, L. Distribution habitat and biomass of Pittosporum undulatum, the most important woody plant invader in the Azores Archipelago. For. Ecol. Manage. 2011, 262, 178-187. [CrossRef]

35. Karger, D.N.; Conrad, O.; Böhner, J.; Kawohl, T.; Kreft, H.; Soria-Auza, R.W.; Zimmermann, N.E.; Linder, H.P.; Kessler, M. Climatologies at high resolution for the earth's land surface areas. Sci. Data 2017, 4, 170122. [CrossRef]

36. Ricardo, R.P.; Madeira, M.V.; Medina, J.M.B.; Marques, M.M.; Furtado, A.F.S. Esboço pedológico da Ilha de S. Miguel (Açores). An. Inst. Sup. Agron. 1977, 37, 275-385.

37. APG. An update of the Angiosperm Phylogeny Group classification for the orders and families of flowering plants: APG IV. Bot. J. Linn. Soc. 2016, 181, 1-20. [CrossRef]

38. Christenhusz, M.J.M.; Byng, J.W. The number of known plants species in the world and its annual increase. Phytotaxa 2016, 261, 201-217. [CrossRef] 
39. Renner, S.S. Circumscription and phylogeny of the Laurales: Evidence from molecular and morphological data. Am. J. Bot. 1999, 86, 1301-1315. [CrossRef] [PubMed]

40. Rohwer, J.G. Toward a phylogenetic classification of the Lauraceae: Evidence from matK sequences. Syst. Botany. 2000, 25, 60-71. [CrossRef]

41. Chanderbali, A.S.; van der Werff, H.; Renner, S.S. Phylogeny and historical biogeography of Lauraceae: Evidence from the chloroplast and nuclear genomes. Ann. Mo. Bot. Gard. 2001, 88, 104-134. [CrossRef]

42. Rohwer, J.G.; Rudolph, B. Jumping genera: The phylogenetic positions of Cassytha, Hypodaphnis, and Neocinnamomum (Lauraceae) based on different analyses of trnK intron sequences. Ann. Mo. Bot. Gard. 2005, 92, 153-178.

43. Quinet, A.; Andreata, H.R.P. Lauraceae Jussieu na reserva ecológica de Macaéde Cima, município de Nova Friburgo, Rio de Janeiro, Brasil. Rodriguésia 2002, 53, 59-121. [CrossRef]

44. Fernández-Palacios, J.M.; Arévalo, J.R.; Balguerías, E.; Barone, R.; de Nascimento, L.; Elias, R.B.; Delgado, J.D.; Fernández-Lugo, S.; Méndez, J.; Naranjo Cigala, A.; et al. La Laurisilva. In Canarias, Madeira y Azores; Macaronesia Editorial: Santa Cruz de Tenerife, Spain, 2017; p. 420.

45. Vieira, C.M.; Vaz, A.M.S.F.; Lima, H.C. Espécies de Interesse Conservacionista na Reserva Ecológica de Macaé de Cima. In Serra de Macaé de Cima: Diversidade Florística e Conservação; Lima, H.C., Guedes-Bruni, R.R., Eds.; Mata Atlântica, Instituto de Pesquisas Jardim Botânico do Rio de Janeiro: Rio de Janeiro, Brazil, 1997; pp. 297-305.

46. Marques, C.A. Importância Econômica da Família Lauraceae. Floresta e Ambiente 2001, 8, 195-206.

47. IUCN. The IUCN Red List of Threatened Species. Version 2017.3. Available online: www.iucnredlist.org (accessed on 7 April 2018).

48. Köhl, M.; Magnussen, S.S.; Marchetti, M. Sampling Methods, Remote Sensing and GIS Multiresource Forest Inventory. In Tropical Forestry; Springer: Berlin, Germany, 2006; p. 373.

49. Rossi, S.; Anfodillo, T.; Menardi, R. Trephor: A new tool for sampling microcores from tree stems. IAWA J. 2006, 27, 89-97. [CrossRef]

50. Worbes, M. Tree-Ring Analysis; Elsevier Ltd.: Amsterdam, The Netherlands, 2004. [CrossRef]

51. Prislan, P.; Gričar, J.; Čufar, K. Wood Sample Preparation for Microscopic Analysis. STREeSS COST 2014, 8.

52. Van der Werf, G.W.; Sass-Klaassen, U.; Mohren, G.M.J. The impact of the 2003 summer drought on the intra-annual growth pattern of beech (Fagus sylvatica L.) and oak (Quercus robur L.) on a dry site in the Netherlands. Dendrochronologia 2007, 25, 103-112. [CrossRef]

53. Bettinger, P.; Boston, K.; Siry, J.P.; Grebne, L.D. Forest Management and Planning; Academic Press: Cambridge, MA, USA, 2017; Chapter 2; p. 362.

54. Semenzato, P.; Cattaneo, D.; Dainese, M. Growth prediction for five tree species in an Italian urban forest. Urban For. Urban Green. 2011, 10, 169-176. [CrossRef]

55. Troxel, B.; Piana, M.; Ashton, M.S.; Murphy-Dunning, C. Relationships between bole and crown size for young urban trees in the northeastern USA. Urban For. Urban Green. 2013, 12, 144-153. [CrossRef]

56. Burnham, K.P.; Anderson, D.R. Model Selection and Inference: A Practical Information-Theoretic Approach, 2nd ed.; Springer: New York, NY, USA, 2002. [CrossRef]

57. R Core Team. R: A Language and Environment for Statistical Computing; R Foundation for Statistical Computing: Vienna, Austria, 2016.

58. Silva, L.; Ojeda-Land, E.; Rodriguez-Luengo, J.L. (Eds.) Invasive Terrestrial Flora and Fauna of Macaronesia. Top 100 in Azores; Madeira and Canaries, ARENA: Ponta Delgada, Portugal, 2008; p. 546.

59. Caviedes, J.; Ibarra, J.T. Influence of Anthropogenic Disturbances on Stand Structural Complexity in Andean Temperate Forests: Implications for Managing Key Habitat for Biodiversity. PLoS ONE 2017, 12, e0169450. [CrossRef] [PubMed]

60. Elias, R.B.; Dias, E. Gap Dynamics and regeneration strategies in Juniperus-Laurus forests of the Azores Islands. Plant. Ecol. 2009, 200, 179-189. [CrossRef]

61. Shishov, V.V.; Tychkov, I.I.; Popkova, M.I.; Ilyin, V.A.; Bryukhanova, M.V.; Kirdyanov, A.V. VS-oscilloscope: A new tool to parameterize tree radial growth based on climate conditions. Dendrochronologia 2016, 39, 42-50. [CrossRef]

62. Schweingruber, F.H. Anatomy of European Woods; Verlag Paul Haupt: Bern, Switzerland, 1990.

63. Schweingruber, F.H.; Börner, A.; Schulze, E.-D. Atlas of Stem Anatomy in Herbs, Shrubs and Trees; Springer-Verlag: Berlin, Germany, 2011; Volume 1, p. 495. 
64. Albuquerque, A.R.; Castro, V.R.; Lobão, M.S.; Sarto, C.; Tomazello Filho, M.; Guedes, F.T.P. Comparative analysis of anatomy and micro-densitometry of the growth rings of hardwoods and conifers, with emphasis on dendrochronology. Sci. For. 2016, 44, 595-610. [CrossRef]

65. Kraus, J.E.; de Sousa, H.C.; Rezende, M.H.; Castro, N.M.; Vecchi, C.; Luque, R. Astra Blue and Basic Fuchsin Double Staining of Plant Materials. Biotech. Histochem. 1998, 73, 235-243. [CrossRef]

66. Shestakova, T.A.; Gutiérrez, E.; Kirdyanov, A.V.; Camarero, J.J.; Génova, M.; Knorre, A.A.; Linares, J.C.; Resco de Dios, V.; Sánchez-Salguero, R.; Voltas, J. Forests synchronize their growth in contrasting Eurasian regions in response to climate warming. Proc. Natl. Acad. Sci. USA 2016, 113, 662-667. [CrossRef]

67. Morris, H.E.R. The Structure and Function of Ray and Axial Parenchyma in Woody Seed Plants. Master's Thesis, Ulm University, Ulm, Germany, 2016; p. 171. [CrossRef]

68. Schöngart, J.; Arieira, J.; Fortes, C.F.; Cezarine de Arruda, E.; Nunes da Cunha, C. Age-related and stand-wise estimates of carbon stocks and sequestration in the aboveground coarse wood biomass of wetland forests in the northern Pantanal, Brazil. Biogeosciences 2011, 8, 3407-3421. [CrossRef]

69. McPherson, E.; van Doorn, G.; Natalie, S.; Paula, J. Urban Tree Database and Allometric Equations; Gen. Tech. Rep. PSW-GTR-235; Department of Agriculture, Forest Service, Pacific Southwest Research Station: Albany, CA, USA, 2016; p. 86. [CrossRef]

70. Diallo, A.; Agbangba, E.C.; Ndiaye, O.; Guisse, A. Ecological Structure and Prediction Equations for Estimating Tree Age, and Dendometric Parameters of Acacia senegal in the Senegalese Semi-Arid Zone-Ferlo. Am. J. Plant Sci. 2013, 4, 1046-1053. [CrossRef]

71. Gonzalez-Benecke, C.A.; Flamenco, H.N.; Wightman, M.G. Effect of Vegetation Management and Site Conditions on Volume, Biomass and Leaf Area Allometry of Four Coniferous Species in the Pacific Northwest United States. Forests 2018, 9, 581. [CrossRef]

72. Yang, B.; Xue, W.; Yu, S.; Zhou, J.; Zhang, W. Effects of Stand Age on Biomass Allocation and Allometry of Quercus Acutissima in the Central Loess Plateau of China. Forests 2019, 10, 41. [CrossRef]

73. Gonçalves, G.V. Dendrocronologia: Princípios teóricos, problemas práticos e aplicabilidade. CIDEHUS. Universidade de Evora, PT. Consultado julho 2012, 23.

74. Tinker, D.G.; Stakes, K.A. Allometric equation development, biomass and aboveground productivity in ponderosa pine forests Black Hill, Wyoming. West J. Appl. For. 2010, 25, 112-119.

75. Vahedi, A.A.; Mataji, A.; Babayi-Kafaki, S.; Eshaghi-Rad, J.; Hodjati, S.M.; Djomo, A. Allometric equations for predicting aboveground biomass of beech-hornbeam stands in the Hyrcanian forests of Iran. JFS 2014, 60, 236-247. [CrossRef]

76. Sillett, S.C.; Van Pelt, R.; Koch, G.W.; Ambrose, A.R.; Carroll, A.L.; Antoine, M.E.; Mifsud, B.M. Increasing wood production through old age in tall trees. For. Ecol. Manag. 2010, 259, 976-994. [CrossRef]

77. Schuster, R.; Oberhuber, W. Age-dependent climate-growth relationships and regeneration of Picea abies in a drought-prone mixed coniferous forest in the Alps. Can. J. For. Res. 2013, 43, 609-618. [CrossRef]

78. Hess, A.F.; Loiola, T.; Souza, I.A.; Minatti, M.; Ricken, P.; Borsoi, G.A. Forest management for the conservation of Araucaria angustifolia in southern brazil. Floresta 2018, 48, 373-382. [CrossRef]

(C) 2019 by the authors. Licensee MDPI, Basel, Switzerland. This article is an open access article distributed under the terms and conditions of the Creative Commons Attribution (CC BY) license (http://creativecommons.org/licenses/by/4.0/). 